\title{
The diagnostic accuracy of the natriuretic peptides in heart failure: systematic review and diagnostic meta-analysis in the acute care setting
}

\author{
(c) (1) (8) OPEN ACCESS
}

\begin{abstract}
Emmert Roberts academic clinical fellow in psychiatry ${ }^{1}$, Andrew J Ludman consultant cardiologist ${ }^{2}$, Katharina Dworzynski senior research fellow ${ }^{3}$, Abdallah Al-Mohammad consultant cardiologist ${ }^{4}$, Martin R Cowie professor of cardiology ${ }^{5}$, John J V McMurray professor of cardiology ${ }^{6}$, Jonathan Mant professor of primary care research ${ }^{7}$, on behalf of the NICE Guideline Development Group for Acute Heart Failure
\end{abstract}

\begin{abstract}
${ }^{1}$ Maudsley Hospital, South London and the Maudsley Mental Health Trust, London, UK; ${ }^{2}$ Royal Devon \& Exeter NHS Foundation Trust, Wonford, Exeter EX2 5DW, UK; ${ }^{3}$ National Clinical Guideline Centre, Royal College of Physicians, London, UK; ${ }^{4}$ South Yorkshire Cardiothoracic Centre, Sheffield Teaching Hospitals NHS Foundation Trust, Sheffield, UK; ${ }^{5}$ National Heart and Lung Institute, Imperial College London (Royal Brompton Hospital), London, UK; ${ }^{6}$ British Heart Foundation (BHF) Cardiovascular Research Centre, University of Glasgow, Glasgow, UK; ${ }^{7}$ Primary Care Unit, Department of Public Health \& Primary Care, Strangeways Research Laboratory, University of Cambridge, Cambridge, UK
\end{abstract}

\section{Abstract}

Objectives To determine and compare the diagnostic accuracy of serum natriuretic peptide levels ( $B$ type natriuretic peptide, $N$ terminal probrain natriuretic peptide (NTproBNP), and mid-regional proatrial natriuretic peptide (MRproANP)) in people presenting with acute heart failure to acute care settings using thresholds recommended in the 2012 European Society of Cardiology guidelines for heart failure.

Design Systematic review and diagnostic meta-analysis.

Data sources Medline, Embase, Cochrane central register of controlled trials, Cochrane database of systematic reviews, database of abstracts of reviews of effects, NHS economic evaluation database, and Health Technology Assessment up to 28 January 2014, using combinations of subject headings and terms relating to heart failure and natriuretic peptides.

Eligibility criteria for selecting studies Eligible studies evaluated one or more natriuretic peptides (B type natriuretic peptide, NTproBNP, or MRproANP) in the diagnosis of acute heart failure against an acceptable reference standard in consecutive or randomly selected adults in an acute care setting. Studies were excluded if they did not present sufficient data to extract or calculate true positives, false positives, false negatives, and true negatives, or report age independent natriuretic peptide thresholds. Studies not available in English were also excluded.

Results 37 unique study cohorts described in 42 study reports were included, with a total of 48 test evaluations reporting 15263 test results.
\end{abstract}

At the lower recommended thresholds of $100 \mathrm{ng} / \mathrm{L}$ for $\mathrm{B}$ type natriuretic peptide and $300 \mathrm{ng} / \mathrm{L}$ for NTproBNP, the natriuretic peptides have sensitivities of 0.95 ( $95 \%$ confidence interval 0.93 to 0.96$)$ and $0.99(0.97$ to 1.00$)$ and negative predictive values of 0.94 ( 0.90 to 0.96$)$ and 0.98 (0.89 to 1.0), respectively, for a diagnosis of acute heart failure. At the lower recommended threshold of $120 \mathrm{pmol} / \mathrm{L}, \mathrm{MRproANP}$ has a sensitivity ranging from 0.95 (range $0.90-0.98$ ) to $0.97(0.95-0.98$ ) and a negative predictive value ranging from $0.90(0.80-0.96)$ to $0.97(0.96-0.98)$. At higher thresholds the sensitivity declined progressively and specificity remained variable across the range of values. There was no statistically significant difference in diagnostic accuracy between plasma $B$ type natriuretic peptide and NTproBNP.

Conclusions At the rule-out thresholds recommended in the 2012 European Society of Cardiology guidelines for heart failure, plasma $B$ type natriuretic peptide, NTproBNP, and MRproANP have excellent ability to exclude acute heart failure. Specificity is variable, and so imaging to confirm a diagnosis of heart failure is required. There is no statistical difference between the diagnostic accuracy of plasma B type natriuretic peptide and NTproBNP. Introduction of natriuretic peptide measurement in the investigation of patients with suspected acute heart failure has the potential to allow rapid and accurate exclusion of the diagnosis. 


\section{Introduction}

Making the correct diagnosis in patients with suspected acute heart failure is challenging, and confirmatory in only $40-50 \%$ of cases. Several studies have shown that when added to routine history, clinical examination, and conventional investigations (for example, chest radiography), measurement of plasma natriuretic peptide levels improves diagnostic accuracy, and has led to these markers being recommended in international guidelines for the diagnosis and management of heart failure. ${ }^{12}$ The 2012 European Society of Cardiology guidelines for heart failure endorsed specific age independent decision cut-offs for plasma B type natriuretic peptide $(\leq 100 \mathrm{ng} / \mathrm{L}), \mathrm{N}$ terminal probrain natriuretic peptide (NTproBNP, $\leq 300 \mathrm{ng} / \mathrm{L}$ ), and mid-regional proatrial natriuretic peptide (MRproANP, $\leq 120$ $\mathrm{pmol} / \mathrm{L}$ ) for the exclusion of acute heart failure based on consensus of expert opinion. ${ }^{23}$ Although natriuretic peptide levels have been used widely for the earlier diagnosis or exclusion of chronic heart failure in the outpatient setting, their use in the acute care setting has only partially been adopted, because their role has remained uncertain and they are not routinely available in emergency departments in the United Kingdom for rapid assessment of patients presenting with breathlessness. This lack of availability reflects lack of clarity on the diagnostic accuracy of natriuretic peptides in this setting. In particular, while the age independent cut-offs as recommended by the European Society of Cardiology are relatively easy to apply in clinical practice, they have not been evaluated by diagnostic meta-analysis. As part of the development process of a National Institute for Health and Care Excellence guideline on the management of acute heart failure we performed an up to date, diagnostic meta-analysis of the utility of plasma B type natriuretic peptide, NTproBNP, and MRproANP in acute and hospital based care settings at the thresholds recommended by the European Society of Cardiology guidelines.

\section{Methods}

\section{Types of studies}

We considered studies to be eligible if they evaluated one or more natriuretic peptides (B type natriuretic peptide, NTproBNP, or MRproANP) in the diagnosis of heart failure against an acceptable reference standard in a consecutive or randomly selected series of adults (age $\geq 18$ years) in an acute care setting. The reference standard was the diagnosis of heart failure by retrospective review or the final hospital diagnosis. Studies were excluded if they did not present sufficient data to allow us to extract or calculate absolute numbers of true positives, false positives, false negatives, and true negatives or to report age independent natriuretic peptide thresholds. Studies were also excluded if they were not available in English.

For each natriuretic peptide, we grouped data according to prespecified age independent thresholds from the 2012 European Society of Cardiology guidelines for heart failure. Some studies contributed data to more than one threshold analysis per peptide. The ranges used were $\leq 100 \mathrm{ng} / \mathrm{L}, 100-500 \mathrm{ng} / \mathrm{L}$, and $>500 \mathrm{ng} / \mathrm{L}$ for B type natriuretic peptide; $\leq 300 \mathrm{ng} / \mathrm{L}, 300-1800 \mathrm{ng} / \mathrm{L}$, and $>1800 \mathrm{ng} / \mathrm{L}$ for NTproBNP; and $\leq 120 \mathrm{pmol} / \mathrm{L}$ and $>120 \mathrm{pmol} / \mathrm{L}$ for MRproANP.

We excluded studies examining the use of natriuretic peptides in the diagnosis of heart failure in non-acute care settings, the use of urinary natriuretic peptides, screening for left or right ventricular dysfunction, and studies concerning the diagnostic accuracy of natriuretic peptides in pleural effusion of unknown cause.

\section{Search strategies}

For the search strategies we used a combination of subject headings and terms relating to the target condition of interest (heart failure) and the index tests (natriuretic peptides: B type natriuretic peptide, NTproBNP, and MRproANP). Using the search terms and strategies described in the supplementary file we searched Medline, Embase, Cochrane central register of controlled trials, Cochrane database of systematic reviews, database of abstracts of reviews of effects, NHS economic evaluation database, and Health Technology Assessment up to 28 January 2014.

\section{Selection of studies}

One author (ER) initially assessed the titles and then abstracts of papers identified by the search. Two authors (ER and KD) reviewed the full text of the remaining articles. Any discrepancy was resolved by discussion. Where agreement could not be reached, we consulted a third author (JM or AL). Excluded studies are listed in the online supplementary material.

\section{Data extraction and management}

Two authors (ER and KD) independently extracted a standard set of data, with discrepancies resolved by discussion. Where more than one type of assay for the same index test was used (for example, Abbott or Biosite BNP), the more conservative estimate of sensitivity was extracted and included in the review. For each comparison of index test at a particular threshold with a reference standard, we extracted data on the number of true positives, true negatives, false positives, and false negatives.

\section{Assessment of methodological quality}

Two authors (ER and KD) independently assessed the quality of each study using the QUADAS-II checklist (www.bris.ac. uk/quadas/quadas-2).

\section{Statistical analysis and data synthesis}

The comparisons made in this review can be considered in two parts. The first comparison was among studies using the same individual peptide (B type natriuretic peptide, NTpro-BNP, MRpro ANP) according to the three threshold categories. The second comparison was between different peptides at "equivalent" thresholds for ruling out heart failure, as specified in the 2012 European Society of Cardiology guidelines for heart failure. Comparative analyses were conducted across all included studies as well as within studies, with direct comparisons between tests with the same participants. Analyses were conducted in Review Manager version 5.3 and STATA SE version 12 .

For each natriuretic peptide at the prespecified threshold, we plotted estimates of the paired observed sensitivities and specificities in forest plots and as average summary receiver operating characteristic (sROC) curves. These plots show the variation in accuracy between studies. Where adequate data were available we carried out diagnostic meta-analyses. To be able to pool data we required five or more studies for each threshold. We used the bivariate method modelled in Winbugs (Medical Research Council Biostatistics Unit) to pool test accuracy for the studies. The bivariate method uses logistic regression on the true positives, true negatives, false positives, and false negatives reported in the studies. We constructed 
sROCs and plotted confidence regions (using methods outlined by Novielli and colleagues ${ }^{4}$ ). The average operating point for each test was identified on each curve, and average sensitivities and specificities computed. Where insufficient data were available to estimate all variables, we simplified the sROC model by assuming a symmetrical shape to the sROC curve. We assessed the significance of the difference in test performance by using a likelihood ratio test comparing models with and without covariate terms for accuracy at equivalent thresholds.

\section{Investigation of publication bias and heterogeneity}

To assess for the possibility of publication bias for each peptide at each threshold, we constructed funnel plots and performed Deeks' funnel plot asymmetry test, with a P value greater than 0.1 indicating no publication bias. We predefined heterogeneity as an $\mathrm{I}^{2}$ statistic greater than $50 \%$, and calculated $\mathrm{I}^{2}$ for each analysis where there were sufficient studies $(>5)$ for diagnostic meta-analysis. Where heterogeneity was shown, we investigated variation in sensitivity and specificity by adding to the meta-analysis models prespecified covariates indicating acute care setting of presentation, assay of natriuretic peptide used in the study cohort, prevalence of acute heart failure, and overall study quality. We did not carry out sensitivity analyses.

\section{Results}

The search identified 7007 papers, of which 6856 were excluded on the basis of the title and abstract. Full text articles were retrieved for 151 titles, of which 109 were excluded: non-diagnostic accuracy studies $(n=47)$; non-acute care setting $(\mathrm{n}=33)$; systematic reviews $(\mathrm{n}=14)$, cross checked for includable references; not available in English $(\mathrm{n}=8)$; and unable to extract absolute numbers of true positives, false positives, false negatives, and true negatives $(n=7)$. (See the supplementary file for the PRISMA flow diagram and table showing excluded studies.)

A total of 37 unique study cohorts described in 42 study reports were included in the review. In eight of the 37 study cohorts more than one test was evaluated. Thus a total of 48 test evaluations reported a total of 15263 test results. The reference standard diagnosis of heart failure was a clinical diagnosis of a syndrome in which patients have typical symptoms (for example, dyspnoea and peripheral oedema) and signs (for example, raised jugular venous pressure and pulmonary crepitations) resulting from an abnormality of cardiac structure or function.

Retrospective clinical review was the reference standard for 36 test evaluations, and discharge or final hospital diagnosis for 12. Table $1 \Downarrow$ shows the reference standards described in individual studies.

The accuracy of B type natriuretic peptide was assessed in 26 study cohorts. In 19 cohorts (6950 participants) data were reported at the $\leq 100 \mathrm{ng} / \mathrm{L}$ threshold, in 20 cohorts (4543 participants) at the $100-500 \mathrm{ng} / \mathrm{L}$ threshold, and in four cohorts (283 participants) at the $\geq 500 \mathrm{ng} / \mathrm{L}$ threshold.

The accuracy of NTproBNP was assessed in 18 study cohorts. In 10 cohorts (3349 participants) data were reported at the $\leq 300$ $\mathrm{ng} / \mathrm{L}$ threshold, in 13 cohorts (3223 participants) at the 300-1800 $\mathrm{ng} / \mathrm{L}$ threshold, and in three cohorts (840 participants) at the $\geq 1800 \mathrm{ng} / \mathrm{L}$ threshold.

The accuracy of MRproANP was assessed in four study cohorts. In two cohorts (1892 participants) data were reported at the $\leq 120 \mathrm{pmol} / \mathrm{L}$ threshold and in three cohorts (916 participants) at the $>120 \mathrm{pmol} / \mathrm{L}$ threshold. Table 1 provides a summary of the studies assessing each natriuretic peptide.

\section{Methodological quality of included studies}

We used four quality categories (patient selection, reference standard, index test, and flow and timing) to evaluate the risk of bias and applicability of each study cohort and designated an overall high or low risk of bias for each category (see table 1). Just over $50 \%$ of the studies included a representative spectrum of participants attending acute care settings with symptoms suggestive of acute heart failure; most of the remaining studies had inappropriate patient exclusion criteria based on our prespecified patient cohort or had not adequately described the sampling methods. Around $65 \%$ of the studies reported blinding of the reference standard to the results of the index test, and around 70\% reported blinding of the index test to the results of the reference standard. Only around $60 \%$ either explained any withdrawals or was clear that there were no withdrawals and had appropriate sequencing of tests.

\section{B type natriuretic peptide}

When diagnostic meta-analysis was conducted the pooled sensitivity, specificity, positive predictive value, and negative predictive value of B type natriuretic peptide at a threshold of $\leq 100 \mathrm{ng} / \mathrm{L}$ were 0.95 (95\% confidence interval 0.93 to 0.96 ), 0.63 (0.52 to 0.73 ), 0.67 ( 0.63 to 0.75 ), and 0.94 (0.90 to 0.96 ), respectively. At a B type natriuretic peptide level of 100-500 $\mathrm{ng} / \mathrm{L}$, the pooled sensitivity, specificity, positive predictive value, and negative predictive value were 0.85 ( 0.81 to 0.88$)$, 0.86 ( 0.79 to 0.91 ), 0.85 ( 0.78 to 0.90 ), and 0.86 (0.82 to 0.89 ), respectively. As only four study cohorts reported data for $\mathrm{B}$ type natriuretic peptide at a threshold of $\geq 500 \mathrm{ng} / \mathrm{L}$, diagnostic meta-analysis was not performed and the reported sensitivity from the study cohorts ranged from 0.35 (range $0.17-0.56$ ) to $0.83(0.69-0.92)$ and the paired specificity from $0.78(0.56-0.93)$ to $1.0(0.91-1.0)$. At the lowest threshold $(<100 \mathrm{ng} / \mathrm{L})$ sensitivity was consistently high whereas specificity varied widely across all studies (0.26-0.94). As the threshold increased, sensitivity decreased (that is, more cases of heart failure would be missed) and specificity increased yet remained quite variable (fig $1 \Downarrow$ ). Figure $2 \Downarrow$ provides additional information, displaying the summary sensitivity and specificity points compared with the forest plots in figure 1 . The summary point for the threshold of $100-500 \mathrm{ng} / \mathrm{L}$ is clearly lower in the sROC space compared with the $<100 \mathrm{ng} / \mathrm{L}$ threshold, suggesting diagnoses of heart failure would be missed, although the specificity was higher.

\section{$\mathbf{N}$ terminal probrain natriuretic peptide}

When diagnostic meta-analysis was conducted, the pooled sensitivity, specificity, positive predictive value, and negative predictive value of NTproBNP at a threshold of $\leq 300 \mathrm{ng} / \mathrm{L}$ were 0.99 (95\% confidence interval 0.97 to 1.00$), 0.43$ (0.26 to 0.62$)$, 0.64 ( 0.57 to 0.73 ), and 0.98 (0.89 to 1.0$)$, respectively; and at 300 to $1800 \mathrm{ng} / \mathrm{L}$ these variables were 0.90 (0.86 to 0.93$), 0.76$ ( 0.69 to 0.82$), 0.80$ (0.74 to 0.84$)$, and 0.88 ( 0.82 to 0.92$)$, respectively. As only three study cohorts reported data for NTproBNP at a threshold of $\geq 1800 \mathrm{ng} / \mathrm{L}$, diagnostic meta-analysis was not performed and the reported sensitivity ranged from 0.67 (range $0.60-0.73)$ to $0.87(0.81-0.92)$ and the paired specificity from $0.72(0.63-0.80)$ to $0.95(0.91-0.98)$. The pattern in figures $3 \Downarrow$ and $4 \Downarrow$ mirrors that of $B$ type natriuretic peptide at different thresholds-that is, decreasing sensitivity and increasing specificity with increasing threshold. The 
summary points in figure 4 clearly indicate a decrease in mean sensitivity by threshold.

\section{Mid-regional proatrial natriuretic peptide}

As only four study cohorts reported data for MRproANP, diagnostic meta-analysis was not performed. At a threshold of $\leq 120 \mathrm{pmol} / \mathrm{L}$ the sensitivity of MRproANP ranged from 0.95 (range $0.90-0.98)$ to $0.97(0.95-0.98)$ and the paired specificity ranged from $0.56(0.47-0.65)$ to $0.60(0.57-0.63)$. At a threshold of $>120 \mathrm{pmol} / \mathrm{L}$ the sensitivity ranged from $0.84(0.77-0.89)$ to $0.98(0.94-1.00)$ and the paired specificity from $0.40(0.34-0.46)$ to $0.84(0.77-0.90)$. With data from only four study cohorts available, the pattern for MRproANP was less clear, with sensitivity remaining high across the two thresholds, although the specificity was variable (figs $5 \Downarrow$ and $6 \Downarrow$ ).

\section{Comparisons between natriuretic peptides}

After diagnostic meta-analysis was conducted, there was a clear overlap of the confidence regions for B type natriuretic peptide versus NTproBNP surrounding the pooled sensitivity and specificity. This overlap suggested no statistically significant difference between tests at the rule-out thresholds of $\leq 100 \mathrm{ng} / \mathrm{L}$ and $\leq 300 \mathrm{ng} / \mathrm{L}$, respectively ( $\mathrm{P}>0.05$ ) (fig $7 \Downarrow$ ).

Using the upper and lower confidence limits of the sensitivity at the rule-out thresholds, the number of false negatives per 1000 were calculated assuming a prevalence ranging from 0.23 to 0.82 (the range in the included study cohorts). At a prevalence of 0.23 there were between 0 and 7 or 9 and 16 false negative diagnoses per 1000; and at a prevalence of 0.82 there were between 33 and 57 or 0 and 25 false negative diagnoses per 1000 , if employing a B type natriuretic peptide strategy or an $\mathrm{N}$ terminal probrain natriuretic peptide strategy, respectively.

\section{Investigations of publication bias and heterogeneity}

Deeks' funnel plot asymmetry test revealed no evidence of publication bias for any peptide at any threshold (see supplementary file). Table $2 \Downarrow$ presents the $\mathrm{I}^{2}$ statistics for each peptide at each threshold. $\mathrm{I}^{2}$ statistics were, as expected in diagnostic meta-analyses, universally more than $50 \%$, owing to differences in patients' underlying diagnoses and comorbidities. Heterogeneity investigations were undertaken to test for differences in natriuretic peptide performance only where sufficient $(\geq 5)$ study cohorts existed to perform diagnostic meta-analysis. The only significant difference was for

NTproBNP $\leq 300 \mathrm{ng} / \mathrm{L}$; when adding prevalence differences into the model the specificity was significantly higher at 0.93 (95\% confidence interval 0.84 to $0.97, \mathrm{P}<0.01$ ). No other significant difference in sensitivity or specificity was noted for all other covariates for all peptides at each studied threshold. Table $3 \Downarrow$ shows the results.

\section{Discussion}

This meta-analysis of the diagnostic accuracy of natriuretic peptide use was performed to inform recommendations within the new National Institute for Health and Care Excellence guideline for the diagnosis and management of people with suspected heart failure in the acute care setting. It is the largest meta-analysis of the use of natriuretic peptides specifically in the acute care setting, and the first to specifically investigate and compare the different natriuretic peptides at the cut-off thresholds defined within the 2012 European Society of Cardiology guidelines for heart failure for the diagnosis and exclusion of acute heart failure. ${ }^{2}$ Our results show that both B type natriuretic peptide and $\mathrm{N}$ terminal probrain natriuretic peptide (NTproBNP) have excellent ability to exclude the diagnosis of acute heart failure at their respective lower cut-off thresholds, with sensitivities approaching 1 and will therefore miss few, if any, cases of possible acute heart failure when used as a rule-out test. Mid-regional proatrial natriuretic peptide (MRproANP) at a threshold of $<120 \mathrm{pmol} / \mathrm{L}$ also has a sensitivity close to 1 , but there are too few suitable studies to date with which to perform a meta-analysis, and the investigation is not yet widely available as a clinical test. The sensitivity of B type natriuretic peptide, NTproBNP, and MRproANP for the diagnosis of acute heart failure at thresholds above this lower cut-off is only modest. Specificity is also relatively low (although it increases with increasing natriuretic peptide value), thus confirmatory testing by cardiac imaging is required.

The diagnosis of heart failure is often challenging: the symptoms and signs may be non-specific and may occur in other non-cardiac diseases. The mortality from acute heart failure remains high, at approximately $25 \%$ over one year, ${ }^{47}$ and this may be reduced by prompt diagnosis and treatment. The early use of a natriuretic peptide test to rule out acute heart failure, at the diagnostic thresholds evaluated in this meta-analysis, can reliably exclude heart failure and allow more rapid investigation of other potential causes for a patient's symptoms. A negative test result may reduce or obviate the need to proceed to echocardiography or other cardiac imaging, allowing more efficient use of resources. In a similar fashion, in patients where the clinical assessment is difficult, the ability to rapidly raise the suspicion of acute heart failure when the result for natriuretic peptide is above the cut-off, will allow targeted, rapid investigation to confirm or refute the diagnosis. Earlier confirmation of the diagnosis of heart failure may facilitate more rapid initiation of specific treatment, potentially shortening hospital stay and reducing mortality. ${ }^{48}$

When B type natriuretic peptide was compared with NTproBNP, there was no statistically significant difference in their diagnostic ability at the rule-out thresholds examined. When converted to absolute patient numbers the use of $B$ type natriuretic peptide rather than NTproBNP in an acute care setting potentially increased the false negative test results by between 8 and 31 more people per 1000 people (assuming a prevalence ranging from 0.23 to 0.82 , the range in the included study cohorts). Sensitivity was similar and specificity only modest for both natriuretic peptides in the low to intermediate ranges of measured values. Therefore it is important that for values measured above the rule-out thresholds, the information is correlated with clinical and imaging assessment to confirm a diagnosis of heart failure and to exclude non-cardiac causes of an increased natriuretic peptide level (such as pulmonary embolus, sepsis, or renal failure) ${ }^{3}$ Similarly, once heart failure is thought to be likely because of clinical and natriuretic peptide evidence, further assessment (generally with echocardiography) is required to confirm the diagnosis and inform future management.

As with any test, the pretest probability is important and the result must be interpreted in the clinical context. If the clinical scenario is strongly suggestive of heart failure or, conversely, points towards an alternative diagnosis, there is no need to perform the assay for diagnostic purposes. For example, in a patient in whom dyspnoea is associated with a known cause, such as an adult presenting with trauma, measurement of the natriuretic peptide level is not needed.

In the United Kingdom the availability and use of natriuretic peptides is patchy and tests are not routinely available in acute 
care settings, despite accumulating evidence and national guidelines advocating their use. ${ }^{4}$ The barriers to introduction and use have not been reported but we speculate them to include perceived excessive additional cost, a perceived lack of additional diagnostic value, or uncertainty as to which natriuretic peptide to use and their relative merits.

A previous meta-analysis comparing B type natriuretic peptide with NTproBNP in the setting of acute heart failure only evaluated studies that compared paired sampling of both natriuretic peptides. ${ }^{49}$ Therefore, although diagnostic accuracy data were reported for each natriuretic peptide, not all relevant studies were included. However, no significant difference was found between B type natriuretic peptide and NTproBNP, which agrees with our findings. Worster and colleagues ${ }^{50}$ performed a meta-analysis of nine studies (six for B type natriuretic peptide and three for NTproBNP), published during or before 2004, evaluating the use of natriuretic peptides in acute care settings for the diagnosis of dyspnoea. Worster and colleagues also reported no difference between $B$ type natriuretic peptide and NTproBNP, with similarly high diagnostic sensitivity and modest specificity. However, our analysis included a significantly larger numbers of studies, was not limited to dyspnoea, as people may present acutely with several different symptoms, and evaluated the accuracy at specific cut-off points to inform current clinical practice. A meta-analysis of MRproANP in the evaluation of dyspnoea in the emergency department ${ }^{51}$ showed a diagnostic pooled sensitivity of 0.90 (95\% confidence interval 0.88 to 0.92 ) and pooled specificity of 0.68 ( 0.66 to 0.70 ) for the diagnosis of heart failure. However, our specific analysis of age independent data using the suggested rule-out threshold of $<120 \mathrm{pmol} / \mathrm{L}$ gives a higher sensitivity of 0.95 ( 0.90 to 0.98$)$ and paired specificity of 0.56 (0.47 to 0.65$)$, suggesting that measurement of MRproANP may also be a valuable rule-out test for heart failure. Whether or not the test offers any other specific additional advantage remains to be determined.

The exhaustive meta-analysis performed shows that both B type natriuretic peptide and NTproBNP have similar, excellent negative predictive value. Therefore, whichever natriuretic peptide is available locally can be used reliably. No statistically significant differences were detected for their use within a specific care setting or by type of assay used (point of care or laboratory test).

\section{Limitations of this study}

The diagnostic values and cut-off thresholds for use of natriuretic peptides in people with suspected heart failure in the outpatient setting are different-associated with different (generally reduced) sensitivity and specificity—and so the results presented here are only applicable to patients presenting acutely. We have examined age independent cut-off values to validate the recommendations of the European Society of Cardiology guideline and to allow ease of introduction in acute clinical settings. A negative test result remains reassuring at any age, and the impact of factors affecting the serum level of natriuretic peptide (sex, age, body mass index) is less pronounced in acute heart failure than in chronic heart failure. The level of serum natriuretic peptide may increase with age, reducing the specificity in some groups, but this will not affect sensitivity.

Most studies in this review were performed within the emergency department, but we also included studies in other acute settings if natriuretic peptide was being used to differentiate heart failure from other diagnoses. As diagnostic thresholds vary depending on clinical characteristics, this may limit applicability in some settings. Studies in patients after cardiac surgery were specifically excluded and in studies with a higher previous risk or prevalence of acute heart failure the negative predictive value and sensitivity would tend to be lower.

In most studies the ideal diagnostic test was taken as a retrospective synthesis of clinical and imaging data, but was heterogeneous between studies. This is not likely to have affected the sensitivity results to any major degree but may account partly for variability in reported specificity. An individual patient meta-analysis would be technically possible to address this research question, but it is unlikely to expand further on the current review owing to the observed high sensitivity and negative predictive values calculated in an overall population of widely varying prevalence.

In this analysis we did not examine the role of natriuretic peptide use in guiding treatment or in informing prognosis in this setting. Although B type natriuretic peptide and NTproBNP are routinely available in hospital laboratories, MRproANP remains primarily a research tool.

\section{Conclusions}

The use of NTproBNP and B type natriuretic peptide at the rule-out threshold recommended by the recent European Society of Cardiology guidelines on heart failure provides excellent ability to exclude acute heart failure in the acute setting with reassuringly high sensitivity. The specificity is modest at all but the highest values of natriuretic peptide, therefore confirmatory testing by cardiac imaging is required in patients with positive test results. Use of natriuretic peptide may allow the streamlining of investigation, potentially leading to cost savings through removing or reducing the need for echocardiography in patients with natriuretic peptide levels below the cut-off threshold or by facilitating more rapid investigation of non-cardiac disease.

For their help in the preparation of this work we thank: Peter Bolton, Jane Butler, Amelia Ch'ng, Jill Cobb, Alice Ferns, Edward Griffin, Lina Gulhane, Suzanna Hardman, Nicholas Ioannou, Christopher Jones, Jason Kendall, Jayne Masters, Tanzeem Raza, and Gill Ritchie.

Contributors: ER and AJL are joint first authors. ER and KD performed the initial sift of papers and meta-analysis with additional assistance from AJL and JM. All authors discussed and critically appraised the data as part of the NICE guideline development group on acute heart failure. AJL, JJVMcM, MRC, AA-M, and JM decided to prepare the work for publication. ER and AJL wrote the first draft and all authors contributed critically to subsequent revisions. AJL and JM are the guarantors. The funder had no role in the study design; data collection, analysis, and interpretation; writing of the report; or the decision to submit for publication. The researchers were independent from the funder. All authors had full access to all the data and take responsibility for the integrity and accuracy of the data analysis.

Funding: The review was commissioned by the National Institute of Health and Care Excellence as part of work to formulate national guidance on the diagnosis and management of acute heart failure. Competing interests: All authors have completed the ICMJE uniform disclosure form at www.icmje.org/coi_disclosure.pdf (available on request from the corresponding author) and declare: MRC's salary was supported by the National Institute for Health Research Cardiovascular Biomedical Research Unit at the Royal Brompton Hospital, London but no authors have support from any company for the submitted work; $\mathrm{MRC}$ has received honorariums within the past three years from Roche Diagnostics for lecturing on the use of natriuretic peptides in the diagnosis of heart failure, no other author has a relationship with a company that might have an interest in the submitted work in the 


\section{What is already known on this topic}

Acute heart failure is the commonest cause of hospital admission in the United Kingdom in people aged over 65 years, and mortality remains high

Diagnosis of acute heart failure is often difficult and the measurement of serum natriuretic peptides in the acute setting may be useful, but has not been widely adopted in the United Kingdom

The 2012 European Society of Cardiology (ESC) guidelines for heart failure suggested rule-out thresholds for natriuretic peptides in the acute setting, but the diagnostic accuracy at these thresholds is not known

\section{What this study adds}

At the rule-out thresholds recommended in the 2012 ESC guidelines for heart failure, B type natriuretic peptide, $\mathrm{N}$ terminal probrain natriuretic peptide, and mid-regional proatrial natriuretic peptide have excellent ability to exclude acute heart failure and miss few cases The specificity of the natriuretic peptides is modest and variable, and therefore confirmatory diagnostic testing by cardiac imaging is required in the case of positive results

The addition of testing for serum natriuretic peptides to acute care settings in patients with suspected heart failure has the potential to accurately streamline investigation and improve the early detection of heart failure

previous three years; no other relationships or activities that could appear to have influenced the submitted work.

Ethical approval: Not required.

Data sharing: No additional data available.

Transparency: The lead authors (AJL and JM) had final responsibility for the decision to submit for publication and affirm that the manuscript is an honest, accurate, and transparent account of the study being reported; that no important aspects of the study have been omitted; and that any discrepancies from the study as planned have been explained.

1 Yancy CW, Jessup M, Bozkurt B, Butler J, Casey DE, Drazner M, et al. ACCF/AHA guideline for the management of heart failure: a report of the American College of Cardiology Foundation/American Heart Association Task Force on practice guidelines Circulation 2013;128:e240-327.

2 McMurray JJV, Adamopoulos S, Anker SD, Auricchio A, Bohm M, Dickstein K, et al. ESC guidelines for the diagnosis and treatment of acute and chronic heart failure 2012. The Task Force for the Diagnosis and Treatment of Acute and Chronic Heart Failure 2012 of the European Society of Cardiology. Developed in collaboration with the Heart Failure Association (HFA) of the ESC. Eur J Heart Fail 2012;14:803-69.

3 Thygesen K1, Mair J, Mueller C, Huber K, Weber M, Plebani M, et al. Recommendations for the use of natriuretic peptides in acute cardiac care: a position statement from the Study Group on Biomarkers in Cardiology of the ESC Working Group on Acute Cardiac Care Eur Heart J 2012;33:2001-6.

4 Novielli N, Cooper NJ, Abrams KR, Sutton AJ. How is evidence on test performance synthesized for economic decision models of diagnostic tests? A systematic appraisal of Health Technology Assessments in the UK since 1997. Value Health 2010;13:952-7.

5 Fleischer D, Espiner EA, Yandle TG, Livesey JH, Billings J, Town I, et al. Rapid assay of plasma brain natriuretic peptide in the assessment of acute dyspnoea. $N Z$ Med $J$ 1997:110:71-4.

6 Dao Q, Krishnaswamy P, Kazanegra R, Harrison A, Amirnovin R, Lenert L, et al. Utility of B-type natriuretic peptide in the diagnosis of congestive heart failure in an urgent-care setting. J Am Coll Cardiol 2001;37:379-85.

7 Logeart D, Saudubray C, Beyne P, Thabut G, Ennezat PV, Chavelas C, et al. Comparative value of Doppler echocardiography and B-type natriuretic peptide assay in the etiologic diagnosis of acute dyspnea. J Am Coll Cardiol 2002;40:1794-800.

8 Maisel AS, Krishnaswamy P, Nowak RM, McCord J, Hollander JE, Duc P, et al. Rapid measurement of B-type natriuretic peptide in the emergency diagnosis of heart failure. $N$ Engl J Med 2002;347:161-7.

9 Villacorta H, Duarte A, Duarte NM, Carrano A, Mesquita ET, Dohmann HJ, et al. The role of B-type natriuretic peptide in the diagnosis of congestive heart failure in patients presenting to an emergency department with dyspnea. Arq Bras Cardiol 2002:79:569-72.

10 Lainchbury JG, Campbell E, Frampton CM, Yandle TG, Nicholls MG, Richards AM. Brain natriuretic peptide and $n$-terminal brain natriuretic peptide in the diagnosis of heart failure in patients with acute shortness of breath. J Am Coll Cardiol 2003;42:728-35.

11 Januzzi JL, van Kimmenade R, Lainchbury J, Bayes-Genis A, Ordonez-Llanos J, Santalo-Bel M, et al. NT-proBNP testing for diagnosis and short-term prognosis in acute destabilized heart failure: an international pooled analysis of 1256 patients: the International Collaborative of NT-proBNP Study. Eur Heart J 2006;27:330-7.

12 Davis M, Espiner E, Richards G, Billings J, Town I, Neill A, et al. Plasma brain natriuretic peptide in assessment of acute dyspnoea. Lancet 1994;343:440-4.

13 Dokainish H, Zoghbi WA, Lakkis NM, Quinones MA, Nagueh SF. Comparative accuracy of B-type natriuretic peptide and tissue Doppler echocardiography in the diagnosis of congestive heart failure. Am J Cardiol 2004:93:1130-5.

14 Barcarse E, Kazanegra R, Chen A, Chiu A, Clopton P, Maisel A. Combination of B-type natriuretic peptide levels and non-invasive hemodynamic parameters in diagnosing congestive heart failure in the emergency department. Congest Heart Fail 2004;10:171-6.

15 Ray P, Arthaud M, Lefort Y, Birolleau S, Beigelman C, Riou B, et al. Usefulness of B-type natriuretic peptide in elderly patients with acute dyspnea. Intensive Care Med 2004:30:2230-6.

16 Alibay Y, Beauchet A, El Mahmoud R Schmitta C, Brun-Neyd D, M Benoite, et al. Plasma $\mathrm{N}$-terminal pro-brain natriuretic peptide and brain natriuretic peptide in assessment of acute dyspnea. Biomed Pharmacother 2005;59:20-4.

17 Arques S, Roux E, Sbragia P, Gelisse R, Ambrosi P, Pieri B, et al. Comparative accuracy of color M-mode and tissue Doppler echocardiography in the emergency diagnosis of congestive heart failure in chronic hypertensive patients with normal left ventricular ejection fraction. Am J Cardiol 2005;96:1456-9.
18 Chenevier-Gobeaux C, Claessens YE, Voyer S, Desmoulins D, Ekindjian OG. Influence of renal function on N-terminal pro-brain natriuretic peptide (NT-proBNP) in patients admitted for dyspnoea in the Emergency Department: comparison with brain natriuretic peptide (BNP). Clin Chim Acta 2005:361:167-75

19 Chenevier-Gobeaux C, Guerin S, Andre S, Ray P, Cynober L, Gestin S, et al. Midregional pro-atrial natriuretic peptide for the diagnosis of cardiac-related dyspnea according to renal function in the emergency department: a comparison with B-type natriuretic peptide (BNP) and N-terminal proBNP. Clin Chem 2010;56:1708-17.

20 Mueller T, Gegenhuber A, Poelz W, Haltmayer M. Diagnostic accuracy of B type natriuretic peptide and amino terminal proBNP in the emergency diagnosis of heart failure. Heart 2005;91:606-12.

21 Gegenhuber A, Struck J, Poelz W, Pacher R, Morgenthaler NG, Bergmann A, et al. Midregional pro-A-type natriuretic peptide measurements for diagnosis of acute destabilized heart failure in short-of-breath patients: comparison with B-type natriuretic peptide (BNP) and amino-terminal proBNP. Clin Chem 2006;52:827-31.

22 Parab R, Vasudevan A, Brensilver J, Gitler B. Utility of brain natriuretic peptide as a diagnostic tool for congestive heart failure in the elderly. Crit Pathw Cardiol 2005;4:140-4.

23 Ray $\mathrm{P}$, Arthaud M, Birolleau S, Isnard R, Lefort $\mathrm{Y}$, Boddaert J, et al. Comparison of brain natriuretic peptide and probrain natriuretic peptide in the diagnosis of cardiogenic pulmonary edema in patients aged 65 and older. J Am Geriatr Soc 2005;53:643-8.

24 Zaninotto M, Mion M, Altinier S, Pastorello M, Rocco S, Tosato F, et al. NT-proBNP in the differential diagnosis of acute dyspnea in the emergency department. Clin Biochem 2005;38:1041-4

25 Berdague P, Caffin PY, Barazer I, Vergnes C, Sedighian S, Letrillard S, et al. Use of $\mathrm{N}$-terminal prohormone brain natriuretic peptide assay for etiologic diagnosis of acute dyspnea in elderly patients. Am Heart J 2006;151:690-8.

26 Chung T, Sindone A, Foo F, Dwyer A, Paoloni R, Janu MR, et al. Influence of history of heart failure on diagnostic performance and utility of B-type natriuretic peptide testing for acute dyspnea in the emergency department. Am Heart J 2006;152:949-55.

27 Bayes-Genis A, Santalo-Bel M, Zapico-Muniz E, López L, Cotes C, Bellido J, et al. $\mathrm{N}$-terminal probrain natriuretic peptide (NT-proBNP) in the emergency diagnosis and in-hospital monitoring of patients with dyspnoea and ventricular dysfunction. Eur $J$ Heart Fail 2004;6:301-8.

28 Januzzi JLJ, Camargo CA, Anwaruddin S, Baggish AL, Chen AA, Krauser DG, et al. The $\mathrm{N}$-terminal Pro-BNP investigation of dyspnea in the emergency department (PRIDE) study. Am J Cardiol 2005;95:948-54.

29 Sanz MP, Borque L, Rus A, Vicente B, Ramirez Y, Lasa L. Comparison of BNP and NT-proBNP assays in the approach to the emergency diagnosis of acute dyspnea. $J$ Clin Lab Anal 2006;20:227-32.

30 Arques S, Roux E, Sbragia P, Pieri B, Gelisse R, Luccioni R, et al. Usefulness of bedside tissue Doppler echocardiography and B-type natriuretic peptide (BNP) in differentiating congestive heart failure from noncardiac cause of acute dyspnea in elderly patients with a normal left ventricular ejection fraction and permanent, nonvalvular atrial fibrillation: insights from a prospective, monocenter study. Echocardiography 2007;24:499-507.

31 Gorissen C, Baumgarten R, de Groot M, van Haren E, Kragten H, Leers M. Analytical and clinical performance of three natriuretic peptide tests in the emergency room. Clin Chem Lab Med 2007;45:678-84.

32 Karmpaliotis D, Kirtane AJ, Ruisi CP, Polonsky T, Malhotra A, Talmor D, et al. Diagnostic and prognostic utility of brain natriuretic Peptide in subjects admitted to the ICU with hypoxic respiratory failure due to noncardiogenic and cardiogenic pulmonary edema. Chest 2007;131:964-71.

33 Gargani L, Frassi F, Soldati G, Tesorio P, Gheorghiade M, Picano E. Ultrasound lung comets for the differential diagnosis of acute cardiogenic dyspnoea: a comparison with natriuretic peptides. Eur J Heart Fail 2008;10:70-7.

34 Gruson D, Rousseau MF, Ahn S, Van Linden F, Thys F, Ketelslegers JM, et al. Accuracy of $\mathrm{N}$-terminal-pro-atrial natriuretic peptide in patients admitted to emergency department. Scand J Clin Lab Invest 2008;68:410-4.

35 Behnes M, Brueckmann M, Ahmad-Nejad P, Lang S, Wolpert C, Elmas E, et al. Diagnostic performance and cost effectiveness of measurements of plasma $\mathrm{N}$-terminal pro brain natriuretic peptide in patients presenting with acute dyspnea or peripheral edema. Int $J$ Cardiol 2009:135:165-74.

36 Klemen P, Golub M, Grmec S. Combination of quantitative capnometry, N-termina pro-brain natriuretic peptide, and clinical assessment in differentiating acute heart failure from pulmonary disease as cause of acute dyspnea in pre-hospital emergency setting: study of diagnostic accuracy. Croat Med J 2009;50:133-42.

37 Nazerian P, Vanni S, Zanobetti M, Polidori G, Pepe G, Federico R, et al. Diagnostic accuracy of emergency Doppler echocardiography for identification of acute left ventricular heart failure in patients with acute dyspnea: comparison with Boston criteria and $\mathrm{N}$-terminal prohormone brain natriuretic peptide. Acad Emerg Med 2010;17:18-26.

38 Kevin Rogers R, Stehlik J, Stoddard GJ, Greene T, Collins SP, Peacock WF, et al. Adjusting for clinical covariates improves the ability of B-type natriuretic peptide to 
distinguish cardiac from non-cardiac dyspnoea: a sub-study of HEARD-IT. Eur J Heart Fail 2009;11:1043-9.

39 Lokuge A, Lam L, Cameron P, Krum H, de Villiers S, Bystrzycki A, et al. B-type natriuretic peptide testing and the accuracy of heart failure diagnosis in the emergency department. Circ Heart Fail 2010;3:104-10.

40 Maisel A, Mueller C, Nowak R, Peacock WF, Landsberg JW, Ponikowski P, et al. Mid-region pro-hormone markers for diagnosis and prognosis in acute dyspnea: results from the BACH (Biomarkers in Acute Heart Failure) trial. J Am Coll Cardiol 2010;55:2062-76

41 Potocki M, Breidthardt T, Reichlin T, Hartwiger S, Morgenthaler NG, Bergmann A, et al. Comparison of midregional pro-atrial natriuretic peptide with $\mathrm{N}$-terminal pro-B-type natriuretic peptide in the diagnosis of heart failure. $J$ Intern Med 2010;267:119-29.

42 Wang HK, Tsai MS, Chang JH, Wang TD, Chen WJ, Huang CH. Cardiac ultrasound helps for differentiating the causes of acute dyspnea with available B-type natriuretic peptide tests. Am J Emerg Med 2010;28:987-93.

43 Blonde-Cynober F, Morineau G, Estrugo B, Fillie E, Aussel C, Vincent J-P. Diagnostic and prognostic value of brain natriuretic peptide (BNP) concentrations in very elderly hear disease patients: Specific geriatric cut-off and impacts of age, gender, renal dysfunction, and nutritional status. Arch Gerontol Geriatr 2011;52:106-10.

44 Prosen G, Klemen P, Strnad M, Grmec S. Combination of lung ultrasound (a comet-tail sign) and $\mathrm{N}$-terminal pro-brain natriuretic peptide in differentiating acute heart failure from chronic obstructive pulmonary disease and asthma as cause of acute dyspnea in prehospital emergency setting. Crit Care 2011;15:R114.

45 Shaikh K, Ahmad M. Diagnostic significance of NT-proBNP estimation in patients with acute dyspnea. J Coll Physicians Surg Pak 2011;21:584-8.

46 Eckstein J, Potocki M, Murray K, Breidthardt T, Ziller R, Mosimann T, et al. Direct comparison of mid-regional pro-atrial natriuretic peptide with $\mathrm{N}$-terminal pro B-type natriuretic peptide in the diagnosis of patients with atrial fibrillation and dyspnoea. Heart 2012;98:1518-22.
47 National Institute for Cardiovascular Outcomes Research. National heart failure auditApril 2012-March 2013. www.ucl.ac.uk/nicor/audits/heartfailure/documents/annualreports/ hfannual12-13.pdf.

48 Peacock W, Fonarow G, Emerman C, Mills R, Wynne J; ADHERE scientific advisory impact of early initiation of intravenous therapy for acute decompensated heart failure on outcomes in ADHERE. Cardiology 2007;107:44-51.

49 Clerico A, Fontana M, Zyw L, Passino C, Emdin M. Comparison of the diagnostic accuracy of brain natriuretic peptide (BNP) and the N-terminal part of the propeptide of BNP immunoassays in chronic and acute heart failure: a systematic review. Clin Chem 2007;53:813-22.

50 Worster A, Balion CM, Hill SA, Santaguida P, Ismaila A, McKelvie R, et al. Diagnostic accuracy of BNP and NT-proBNP in patients presenting to acute care settings with dyspnea: a systematic review. Clin Biochem 2008;41:250-9.

51 Hu Z, Han Z, Huang Y, Sun Y, LiB, Deng A. Diagnostic power of the mid-regional pro-atrial natriuretic peptide for heart failure patients with dyspnea: a meta-analysis. Clin Biochem 2012;45:1634-9

Accepted: 20 January 2015

\section{Cite this as: BMJ 2015;350:h910}

This is an Open Access article distributed in accordance with the Creative Commons Attribution Non Commercial (CC BY-NC 4.0) license, which permits others to distribute, remix, adapt, build upon this work non-commercially, and license their derivative works on different terms, provided the original work is properly cited and the use is non-commercial. See: http://creativecommons.org/licenses/by-nc/4.0/. 


\section{Tables}

\begin{tabular}{|c|c|c|c|c|c|c|c|}
\hline Study, setting & $\begin{array}{l}\text { No } \\
\text { (mean } \\
\text { age) }\end{array}$ & Design & $\begin{array}{c}\text { No of } \\
\text { men/women }\end{array}$ & $\begin{array}{c}\text { Prevalence } \\
(\%)\end{array}$ & Index test (assay) & Reference standard & Quality (QUADAS-II) \\
\hline $\begin{array}{l}\text { Fleischer } 1997,{ }^{5} \text { acute } \\
\text { admissions }\end{array}$ & $123(68)$ & $\begin{array}{l}\text { Prospective } \\
\text { cohort }\end{array}$ & $69 / 54$ & 43/123 (35) & BNP inhouse assay & $\begin{array}{l}\text { Clinical diagnosis based } \\
\text { on intent to treat heart } \\
\text { failure with diuretics for } \\
24 \text { hours }\end{array}$ & $\begin{array}{l}\text { Patient selection: high; index test: } \\
\text { high; reference standard: high; } \\
\text { flow and timing: low; overall: high }\end{array}$ \\
\hline $\begin{array}{l}\text { Dao } 2001,{ }^{6} \text { emergency } \\
\text { department }\end{array}$ & $250(63)$ & $\begin{array}{l}\text { Cross } \\
\text { sectional }\end{array}$ & $235 / 15$ & $97 / 250(39)$ & $\begin{array}{l}\text { BNP Triage (Biosite, } \\
\text { USA) }\end{array}$ & $\begin{array}{l}\text { Retrospective review by } \\
\text { two cardiologists }\end{array}$ & $\begin{array}{l}\text { Patient selection: high; index test: } \\
\text { low; reference standard: low; flow } \\
\text { and timing: low; overall: high }\end{array}$ \\
\hline $\begin{array}{l}\text { Logeart } 2002,{ }^{7} \text { intensive } \\
\text { care unit }\end{array}$ & $163(71)$ & $\begin{array}{l}\text { Cross } \\
\text { sectional }\end{array}$ & $109 / 54$ & $\begin{array}{c}115 / 163 \\
(71)\end{array}$ & $\begin{array}{l}\text { BNP Triage (Biosite, } \\
\text { USA) }\end{array}$ & $\begin{array}{l}\text { Retrospective review by } \\
\text { two cardiologists and } \\
\text { one pulmonologist }\end{array}$ & $\begin{array}{l}\text { Patient selection: high; index test: } \\
\text { low; reference standard: low; flow } \\
\text { and timing: low; overall: high }\end{array}$ \\
\hline $\begin{array}{l}\text { Maisel 2002, } \\
\text { emergency department }\end{array}$ & $1586(64)$ & $\begin{array}{l}\text { Prospective } \\
\text { cohort }\end{array}$ & $888 / 698$ & $\begin{array}{c}744 / 1586 \\
(47)\end{array}$ & $\begin{array}{l}\text { BNP Triage (Biosite, } \\
\text { USA) }\end{array}$ & $\begin{array}{l}\text { Retrospective review by } \\
\text { two cardiologists }\end{array}$ & $\begin{array}{l}\text { Patient selection: low; index test: } \\
\text { low; reference standard: low; flow } \\
\text { and timing: low; overall: low }\end{array}$ \\
\hline $\begin{array}{l}\text { Villacorta } 2002,{ }^{9} \\
\text { emergency department }\end{array}$ & $70(72)$ & $\begin{array}{l}\text { Cross } \\
\text { sectional }\end{array}$ & $33 / 37$ & $36 / 70(51)$ & $\begin{array}{l}\text { BNP Triage (Biosite, } \\
\text { USA) }\end{array}$ & $\begin{array}{l}\text { Retrospective review by } \\
\text { one cardiologist }\end{array}$ & $\begin{array}{l}\text { Patient selection: low; index test: } \\
\text { low; reference standard: low; flow } \\
\text { and timing: low; overall: low }\end{array}$ \\
\hline 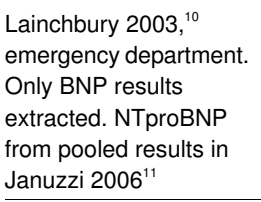 & 205 (70) & $\begin{array}{l}\text { Prospective } \\
\text { cohort }\end{array}$ & $100 / 105$ & $70 / 205(34)$ & $\begin{array}{l}\text { BNP Triage (Biosite, } \\
\text { USA) (+3 inhouse } \\
\text { developed assays; not } \\
\text { extracted in this } \\
\text { analysis) }\end{array}$ & $\begin{array}{l}\text { Retrospective review by } \\
\text { two cardiologists }\end{array}$ & $\begin{array}{l}\text { Patient selection: high; index test: } \\
\text { low; reference standard: low; flow } \\
\text { and timing: low; overall: high }\end{array}$ \\
\hline $\begin{array}{l}\text { Davis } 2004,{ }^{12} \\
\text { emergency department }\end{array}$ & $52(74)$ & $\begin{array}{l}\text { Prospective } \\
\text { cohort }\end{array}$ & $21 / 31$ & $32 / 52(62)$ & BNP inhouse assay & $\begin{array}{l}\text { Retrospective review by } \\
\text { committee of physicians }\end{array}$ & $\begin{array}{l}\text { Patient selection: low; index test: } \\
\text { low; reference standard: low; flow } \\
\text { and timing: low; overall: low }\end{array}$ \\
\hline $\begin{array}{l}\text { Dokanish 2004, }{ }^{13} \\
\text { inpatients }\end{array}$ & $122(56)$ & $\begin{array}{l}\text { Cross } \\
\text { sectional }\end{array}$ & $62 / 60$ & $70 / 122(57)$ & $\begin{array}{l}\text { BNP Triage (Biosite, } \\
\text { USA) }\end{array}$ & $\begin{array}{l}\text { Retrospective review by } \\
\text { one cardiologist }\end{array}$ & $\begin{array}{l}\text { Patient selection: high; index test: } \\
\text { low; reference standard: low; flow } \\
\text { and timing: low; overall: high }\end{array}$ \\
\hline $\begin{array}{l}\text { Barcase } 2004,{ }^{14} \\
\text { emergency department }\end{array}$ & $98(65)$ & $\begin{array}{l}\text { Prospective } \\
\text { cohort }\end{array}$ & $100 / 0$ & $57 / 98(58)$ & $\begin{array}{l}\text { BNP Triage (Biosite, } \\
\text { USA) }\end{array}$ & $\begin{array}{l}\text { Retrospective review by } \\
\text { one cardiologist }\end{array}$ & $\begin{array}{l}\text { Patient selection: low; index test: } \\
\text { high; reference standard: high; } \\
\text { flow and timing: low; overall: high }\end{array}$ \\
\hline $\begin{array}{l}\text { Ray2004, }{ }^{15} \text { emergency } \\
\text { department (overlap } \\
\text { with Ray } 2005 .{ }^{23} \text { Only } \\
\text { BNP results extracted }\end{array}$ & $308(80)$ & $\begin{array}{l}\text { Cross } \\
\text { sectional }\end{array}$ & $154 / 154$ & $\begin{array}{c}141 / 308 \\
(46)\end{array}$ & $\begin{array}{l}\text { BNP Triage (Biosite, } \\
\text { USA) }\end{array}$ & $\begin{array}{l}\text { Retrospective review by } \\
\text { two experts }\end{array}$ & $\begin{array}{l}\text { Patient selection: low; index test: } \\
\text { low; reference standard: low; flow } \\
\text { and timing: low; overall: low }\end{array}$ \\
\hline $\begin{array}{l}\text { Ailbay } 2005,{ }^{16} \\
\text { emergency department }\end{array}$ & $\begin{array}{c}160 \\
(80.1)\end{array}$ & $\begin{array}{l}\text { Cross } \\
\text { sectional }\end{array}$ & $76 / 84$ & $60 / 160(38)$ & $\begin{array}{l}\text { BNP Triage (Biosite, } \\
\text { USA), NTproBNP } \\
\text { Elecsys (Roche, USA) }\end{array}$ & $\begin{array}{l}\text { Retrospective review by } \\
\text { two cardiologists }\end{array}$ & $\begin{array}{l}\text { Patient selection: high; index test: } \\
\text { low; reference standard: low; flow } \\
\text { and timing: low; overall: high }\end{array}$ \\
\hline $\begin{array}{l}\text { Arques } 2005,{ }^{17} \text { acute } \\
\text { referrals }\end{array}$ & 70 (NR) & $\begin{array}{l}\text { Prospective } \\
\text { cohort }\end{array}$ & $35 / 35$ & $32 / 70(46)$ & $\begin{array}{l}\text { BNP Triage (Biosite, } \\
\text { USA) }\end{array}$ & $\begin{array}{l}\text { Retrospective review by } \\
\text { two cardiologists and } \\
\text { one pulmonologist }\end{array}$ & $\begin{array}{l}\text { Patient selection: high; index test: } \\
\text { low; reference standard: high; } \\
\text { flow and timing: low; overall: high }\end{array}$ \\
\hline $\begin{array}{l}\text { Chenevier-Gobeaux } \\
2005{ }^{18} \text { emergency } \\
\text { department. Results } \\
\text { without renal function } \\
\text { stratification from } \\
\text { Chenevier-Gobeaux } \\
2010^{19}\end{array}$ & $378(78)$ & $\begin{array}{l}\text { Prospective } \\
\text { cohort }\end{array}$ & $190 / 188$ & $\begin{array}{c}115 / 378 \\
(30)\end{array}$ & $\begin{array}{l}\text { BNP Triage (Biosite, } \\
\text { USA), NTproBNP } \\
\text { Elecsys (Roche, USA), } \\
\text { MRproANP LIA } \\
\text { (B.R.A.H.M.S, } \\
\text { Germany) }\end{array}$ & $\begin{array}{l}\text { Consensus of two senior } \\
\text { emergency department } \\
\text { physicians }\end{array}$ & $\begin{array}{l}\text { Patient selection: high; index test: } \\
\text { low; reference standard: low; flow } \\
\text { and timing: high; overall: high }\end{array}$ \\
\hline $\begin{array}{l}\text { Mueller } 2005,{ }^{20} \\
\text { emergency department. } \\
\text { MRproANP results from } \\
\text { Gegenhuber } 2006^{21}\end{array}$ & $\begin{array}{c}251 \\
(72.8)\end{array}$ & $\begin{array}{l}\text { Prospective } \\
\text { cohort }\end{array}$ & $234 / 17$ & $\begin{array}{c}137 / 251 \\
(55)\end{array}$ & $\begin{array}{l}\text { BNP Abbott Architecht } \\
\text { (Abbott Diagnostics, } \\
\text { Netherlands), } \\
\text { NTproBNP Elecsys } \\
\text { (Roche, USA), } \\
\text { MRproANP LIA } \\
\text { (B.R.A.H.M.S, } \\
\text { Germany) }\end{array}$ & $\begin{array}{l}\text { Retrospective review by } \\
\text { one study investigator }\end{array}$ & $\begin{array}{l}\text { Patient selection: low; index test: } \\
\text { low; reference standard: low; flow } \\
\text { and timing: low; overall: low }\end{array}$ \\
\hline
\end{tabular}




\section{Table 1 (continued)}

\begin{tabular}{|c|c|c|c|c|c|c|c|}
\hline Study, setting & $\begin{array}{l}\text { No } \\
\text { (mean } \\
\text { age) }\end{array}$ & Design & $\begin{array}{c}\text { No of } \\
\text { men/women }\end{array}$ & $\begin{array}{l}\text { Prevalence } \\
\text { (\%) }\end{array}$ & Index test (assay) & Reference standard & Quality (QUADAS-II) \\
\hline $\begin{array}{l}\text { Parab } 2005{ }^{22} \\
\text { emergency department }\end{array}$ & 70 (76.5) & $\begin{array}{l}\text { Retrospective } \\
\text { cohort }\end{array}$ & $24 / 46$ & $47 / 70(68)$ & $\begin{array}{l}\text { BNP Triage (Biosite, } \\
\text { USA) }\end{array}$ & $\begin{array}{l}\text { Retrospective chart } \\
\text { review }\end{array}$ & $\begin{array}{l}\text { Patient selection: high; index test: } \\
\text { low; reference standard: low; flow } \\
\text { and timing: low; overall: high }\end{array}$ \\
\hline $\begin{array}{l}\text { Ray2005, }{ }^{23} \text { emergency } \\
\text { department. Overlap } \\
\text { with Ray } 2004 .{ }^{15} \text { Only } \\
\text { NTproBNP results } \\
\text { extracted }\end{array}$ & $202(80)$ & $\begin{array}{l}\text { Cross } \\
\text { sectional }\end{array}$ & $100 / 102$ & 88/202 (44) & $\begin{array}{l}\text { NTproBNP Elecsys } \\
\text { (Roche, USA) }\end{array}$ & $\begin{array}{l}\text { Retrospective review by } \\
\text { two experts }\end{array}$ & $\begin{array}{l}\text { Patient selection: low; index test: } \\
\text { low; reference standard: low; flow } \\
\text { and timing: low; overall: low }\end{array}$ \\
\hline $\begin{array}{l}\text { Zaninotto } 2005,{ }^{24} \\
\text { emergency department }\end{array}$ & $122(78)$ & $\begin{array}{l}\text { Prospective } \\
\text { cohort }\end{array}$ & $58 / 64$ & $56 / 122(46)$ & $\begin{array}{l}\text { NTproBNP Elecsys } \\
\text { (Roche, USA) }\end{array}$ & $\begin{array}{l}\text { Diagnosis recorded at } \\
\text { discharge on basis of } \\
\text { clinical and instrumental } \\
\text { investigations }\end{array}$ & $\begin{array}{l}\text { Patient selection: low; index test: } \\
\text { high; reference standard: high; } \\
\text { flow and timing: low; overall: high }\end{array}$ \\
\hline $\begin{array}{l}\text { Berdague } 2006,{ }^{25} \\
\text { emergency department }\end{array}$ & $254(81)$ & $\begin{array}{l}\text { Prospective } \\
\text { cohort }\end{array}$ & $123 / 133$ & $\begin{array}{c}142 / 254 \\
(56)\end{array}$ & $\begin{array}{l}\text { NTproBNP Elecsys } \\
\text { (Roche, USA) }\end{array}$ & $\begin{array}{l}\text { Retrospective review by } \\
\text { two cardiologists }\end{array}$ & $\begin{array}{l}\text { Patient selection: low; index test: } \\
\text { low; reference standard: low; flow } \\
\text { and timing: low; overall: low }\end{array}$ \\
\hline $\begin{array}{l}\text { Chung 2006, }{ }^{26} \\
\text { emergency department }\end{array}$ & $143(79)$ & $\begin{array}{l}\text { Prospective } \\
\text { cohort }\end{array}$ & $63 / 80$ & $72 / 143(50)$ & $\begin{array}{l}\text { BNP Triage (Biosite, } \\
\text { USA) }\end{array}$ & $\begin{array}{l}\text { Retrospective review by } \\
\text { one cardiologist }\end{array}$ & $\begin{array}{l}\text { Patient selection: low; index test: } \\
\text { high; reference standard: high; } \\
\text { flow and timing: low; overall: high }\end{array}$ \\
\hline $\begin{array}{l}\text { Januzzi } 2006,{ }^{11} \\
\text { emergency department; } \\
\text { comprising pooled data } \\
\text { from Lainchbury } 2003,{ }^{10} \\
\text { Bayes-Genis } 2004,{ }^{27} \\
\text { and Januzzi } 2005,{ }^{28} \text { and } \\
\text { unpublished registry } \\
\text { data }\end{array}$ & $\begin{array}{l}1256 \\
(68.3)\end{array}$ & $\begin{array}{l}\text { Pooled } \\
\text { prospective } \\
\text { trial data }\end{array}$ & $641 / 615$ & $\begin{array}{c}720 / 1256 \\
(57)\end{array}$ & $\begin{array}{l}\text { NTproBNP Elecsys } \\
\text { (Roche, USA) }\end{array}$ & $\begin{array}{l}\text { Retrospective review } \\
\text { utilising European } \\
\text { society of cardiology } \\
\text { guidelines. "Suitable for } \\
\text { pooling across studies" }\end{array}$ & $\begin{array}{l}\text { Patient selection: high; index test: } \\
\text { low; reference standard: low; flow } \\
\text { and timing: low; overall: high }\end{array}$ \\
\hline $\begin{array}{l}\text { Sanz } 2006,{ }^{29} \text { emergency } \\
\text { department }\end{array}$ & 75 (75) & $\begin{array}{l}\text { Prospective } \\
\text { cohort }\end{array}$ & NR & $45 / 75(60)$ & $\begin{array}{l}\text { BNP Access } \\
\text { (Beckman Coulter, } \\
\text { USA) (+ BNP Advia } \\
\text { (Bayer Diagnostics, } \\
\text { USA) not extracted), } \\
\text { NTproBNP Elecsys } \\
\text { (Roche, USA) }\end{array}$ & $\begin{array}{l}\text { Diagnosed according to } \\
\text { symptoms and signs and } \\
\text { electrocardiography, } \\
\text { chest radiography, and } \\
\text { in some cases } \\
\text { echocardiography }\end{array}$ & $\begin{array}{l}\text { Patient selection: high; index test: } \\
\text { low; reference standard: high; } \\
\text { flow and timing: low; overall: high }\end{array}$ \\
\hline $\begin{array}{l}\text { Arques } 2007,3^{30} \\
\text { emergency department }\end{array}$ & $41(\mathrm{NR})$ & $\begin{array}{l}\text { Prospective } \\
\text { cohort }\end{array}$ & $17 / 24$ & 22/41 (54) & $\begin{array}{l}\text { BNP Triage (Biosite, } \\
\text { USA) }\end{array}$ & $\begin{array}{l}\text { Retrospective review by } \\
\text { two cardiologist and one } \\
\text { respiratory physician }\end{array}$ & $\begin{array}{l}\text { Patient selection: high; index test: } \\
\text { low; reference standard: low; flow } \\
\text { and timing: low }\end{array}$ \\
\hline $\begin{array}{l}\text { Gorissen } 2007,{ }^{31} \\
\text { emergency department }\end{array}$ & $80(74)$ & $\begin{array}{l}\text { Retrospective } \\
\text { cohort }\end{array}$ & $44 / 36$ & $40 / 80(50)$ & $\begin{array}{l}\text { BNP Triage (Biosite, } \\
\text { USA), NTproBNP } \\
\text { Elecsys (Roche, USA) }\end{array}$ & $\begin{array}{l}\text { Retrospective review by } \\
\text { cardiologist and } \\
\text { pulmonologist }\end{array}$ & $\begin{array}{l}\text { Patient selection: high; index test: } \\
\text { low; reference standard: low; flow } \\
\text { and timing: high; overall: high }\end{array}$ \\
\hline $\begin{array}{l}\text { Karmpaliotis } 2007,,^{32} \\
\text { intensive care unit }\end{array}$ & 74 (NR) & $\begin{array}{l}\text { Prospective } \\
\text { cohort }\end{array}$ & $45 / 35$ & 23/74 (31) & $\begin{array}{l}\text { BNP Triage (Biosite, } \\
\text { USA) }\end{array}$ & $\begin{array}{l}\text { Retrospective review by } \\
\text { two intensivists }\end{array}$ & $\begin{array}{l}\text { Patient selection: high; index test: } \\
\text { low; reference standard: low; flow } \\
\text { and timing: low; overall: high }\end{array}$ \\
\hline $\begin{array}{l}\text { Gargani } 2008{ }^{33} \\
\text { cardiology and } \\
\text { pulmonary admissions }\end{array}$ & 149 (NR) & $\begin{array}{l}\text { Prospective } \\
\text { cohort }\end{array}$ & $98 / 51$ & $\begin{array}{c}122 / 149 \\
(82)\end{array}$ & $\begin{array}{l}\text { NTproBNP Elecsys } \\
\text { (Roche, USA) }\end{array}$ & $\begin{array}{l}\text { Retrospective review by } \\
\text { two cardiologists }\end{array}$ & $\begin{array}{l}\text { Patient selection: high; index test: } \\
\text { low; reference standard: low; flow } \\
\text { and timing: low; overall: high }\end{array}$ \\
\hline $\begin{array}{l}\text { Gruson } 20088^{34} \\
\text { emergency department }\end{array}$ & $137(69)$ & $\begin{array}{l}\text { Prospective } \\
\text { cohort }\end{array}$ & $77 / 60$ & $31 / 137(23)$ & $\begin{array}{l}\text { BNP Access } \\
\text { (Beckman Coulter, } \\
\text { USA), NTproBNP } \\
\text { Elecsys (Roche, USA) }\end{array}$ & $\begin{array}{l}\text { Based on clinical signs, } \\
\text { chest radiography, } \\
\text { echocardiography, } \\
\text { and/or radionuclide } \\
\text { angiography }\end{array}$ & $\begin{array}{l}\text { Patient selection: low; index test: } \\
\text { low; reference standard: low; flow } \\
\text { and timing: low; overall: low }\end{array}$ \\
\hline $\begin{array}{l}\text { Behnes } 2009{ }^{35} \\
\text { emergency department }\end{array}$ & $\begin{array}{c}401 \\
(67.4)\end{array}$ & $\begin{array}{l}\text { Prospective } \\
\text { cohort }\end{array}$ & 205/196 & $\begin{array}{c}122 / 401 \\
(30)\end{array}$ & $\begin{array}{l}\text { NTproBNP Dimension } \\
\text { Dade (Dade-Behring, } \\
\text { USA) }\end{array}$ & $\begin{array}{l}\text { Retrospective review by } \\
\text { study physician }\end{array}$ & $\begin{array}{l}\text { Patient selection: low; index test: } \\
\text { low; reference standard: low; flow } \\
\text { and timing: low; overall: low }\end{array}$ \\
\hline $\begin{array}{l}\text { Klemen } 2009{ }^{36} \\
\text { prehospital emergency }\end{array}$ & $\begin{array}{c}441 \\
(59.1)\end{array}$ & $\begin{array}{l}\text { Prospective } \\
\text { cohort }\end{array}$ & $271 / 170$ & $\begin{array}{c}238 / 441 \\
(54)\end{array}$ & $\begin{array}{l}\text { NTproBNP Elecsys } \\
\text { (Roche, USA) }\end{array}$ & $\begin{array}{l}\text { Final hospital diagnosis } \\
\text { confirmed by } \\
\text { cardiologists and/or } \\
\text { intensivists }\end{array}$ & $\begin{array}{l}\text { Patient selection: low; index test: } \\
\text { low; reference standard: low; flow } \\
\text { and timing: low; overall: low }\end{array}$ \\
\hline $\begin{array}{l}\text { Nazarian } 2009{ }^{37} \\
\text { emergency department }\end{array}$ & 145 (NR) & $\begin{array}{l}\text { Prospective } \\
\text { Cohort }\end{array}$ & NR & $64 / 145(44)$ & $\begin{array}{l}\text { NTproBNP Elecsys } \\
\text { (Roche, USA) }\end{array}$ & $\begin{array}{l}\text { Retrospective review by } \\
\text { two cardiologists and } \\
\text { one respiratory physician }\end{array}$ & $\begin{array}{l}\text { Patient selection: low; index test: } \\
\text { high; reference standard: high; } \\
\text { flow and timing: low; overall: high }\end{array}$ \\
\hline
\end{tabular}


Table 1 (continued)

\begin{tabular}{|c|c|c|c|c|c|c|c|}
\hline Study, setting & $\begin{array}{l}\text { No } \\
\text { (mean } \\
\text { age) }\end{array}$ & Design & $\begin{array}{c}\text { No of } \\
\text { men/women }\end{array}$ & $\begin{array}{c}\text { Prevalence } \\
\text { (\%) }\end{array}$ & Index test (assay) & Reference standard & Quality (QUADAS-II) \\
\hline $\begin{array}{l}\text { Rogers } 2009,^{38} \\
\text { emergency department }\end{array}$ & $740(\mathrm{NR})$ & $\begin{array}{l}\text { Prospective } \\
\text { cohort }\end{array}$ & $399 / 341$ & $\begin{array}{c}368 / 740 \\
(50)\end{array}$ & $\begin{array}{l}\text { BNP ( } 5 \text { sites Triage, } \\
\text { Biosite, USA, } 2 \text { site } \\
\text { Abbott, Netherlands) }\end{array}$ & $\begin{array}{l}\text { Retrospective review by } \\
\text { two cardiologists }\end{array}$ & $\begin{array}{l}\text { Patient selection: high; index test: } \\
\text { high; reference standard: high; } \\
\text { flow and timing: high; overall: } \\
\text { high }\end{array}$ \\
\hline $\begin{array}{l}\text { Lokuge } 2010{ }^{39} \\
\text { emergency department }\end{array}$ & $\begin{array}{c}612 \\
(74.5)\end{array}$ & $\begin{array}{l}\text { Retrospective } \\
\text { cohort }\end{array}$ & $328 / 284$ & $\begin{array}{c}274 / 612 \\
(45)\end{array}$ & $\begin{array}{l}\text { BNP Abbott Architecht } \\
\text { (Abbott Diagnostics, } \\
\text { Netherlands) }\end{array}$ & $\begin{array}{l}\text { Retrospective review by } \\
\text { one physician and one } \\
\text { cardiologist }\end{array}$ & $\begin{array}{l}\text { Patient selection: high; index test: } \\
\text { low; reference standard: low; flow } \\
\text { and timing: low; overall: high }\end{array}$ \\
\hline $\begin{array}{l}\text { Maisel } 2010,{ }^{40} \\
\text { emergency department }\end{array}$ & $\begin{array}{l}1641 \\
(\mathrm{NR})\end{array}$ & $\begin{array}{l}\text { Prospective } \\
\text { cohort }\end{array}$ & $859 / 782$ & $\begin{array}{c}568 / 1641 \\
(39)\end{array}$ & $\begin{array}{l}\text { BNP Triage (Biosite, } \\
\text { USA), MRproANP LIA } \\
\text { (B.R.A.H.M.S, } \\
\text { Germany) }\end{array}$ & $\begin{array}{l}\text { Retrospective review by } \\
\text { two cardiologists }\end{array}$ & $\begin{array}{l}\text { Patient selection: low; index test: } \\
\text { low; reference standard: low; flow } \\
\text { and timing: low; overall: low }\end{array}$ \\
\hline $\begin{array}{l}\text { Potocki } 2010,{ }^{41} \\
\text { emergency department }\end{array}$ & $287(77)$ & $\begin{array}{l}\text { Prospective } \\
\text { cohort }\end{array}$ & $149 / 138$ & $\begin{array}{c}154 / 287 \\
(54)\end{array}$ & $\begin{array}{l}\text { NTproBNP Elecsys } \\
\text { (Roche, USA), } \\
\text { MRproANP LIA } \\
\text { (B.R.A.H.M.S, } \\
\text { Germany) }\end{array}$ & $\begin{array}{l}\text { Retrospective review by } \\
\text { two cardiologists }\end{array}$ & $\begin{array}{l}\text { Patient selection: low; index test: } \\
\text { low; reference standard: low; flow } \\
\text { and timing: low; overall: low }\end{array}$ \\
\hline $\begin{array}{l}\text { Wang } 2010,{ }^{42} \\
\text { emergency department }\end{array}$ & $84(73.5)$ & $\begin{array}{l}\text { Prospective } \\
\text { cohort }\end{array}$ & $40 / 44$ & 49/84 (58) & $\begin{array}{l}\text { BNP Abbott Architecht } \\
\text { (Abbott Diagnostics, } \\
\text { Netherlands) }\end{array}$ & $\begin{array}{l}\text { Retrospective review by } \\
\text { two cardiologists }\end{array}$ & $\begin{array}{l}\text { Patient selection: low; index test: } \\
\text { low; reference standard: low; flow } \\
\text { and timing: low; overall: low }\end{array}$ \\
\hline $\begin{array}{l}\text { Blonde-Cynober 2011, } \\
\text { inpatients }\end{array}$ & 64 (84.3) & $\begin{array}{l}\text { Prospective } \\
\text { cohort }\end{array}$ & $20 / 44$ & $26 / 64(41)$ & $\begin{array}{l}\text { BNP Triage (Biosite, } \\
\text { USA) }\end{array}$ & $\begin{array}{l}\text { Retrospective review by } \\
\text { one cardiologist and one } \\
\text { geriatrician }\end{array}$ & $\begin{array}{l}\text { Patient selection: low; index test: } \\
\text { low; reference standard: low; flow } \\
\text { and timing: low; overall: low }\end{array}$ \\
\hline $\begin{array}{l}\text { Prosen } 2011{ }^{44} \\
\text { prehospital emergency }\end{array}$ & 218 (NR) & $\begin{array}{l}\text { Prospective } \\
\text { cohort }\end{array}$ & NR & $\begin{array}{c}129 / 218 \\
(59)\end{array}$ & $\begin{array}{l}\text { NTproBNP Elecsys } \\
\text { (Roche, USA) }\end{array}$ & $\begin{array}{l}\text { Final hospital diagnosis } \\
\text { confirmed by } \\
\text { cardiologists and or } \\
\text { intensivists }\end{array}$ & $\begin{array}{l}\text { Patient selection: low; index test: } \\
\text { low; reference standard: low; flow } \\
\text { and timing: low; overall: low }\end{array}$ \\
\hline $\begin{array}{l}\text { Shaikh } 2011,{ }^{45} \\
\text { emergency department }\end{array}$ & $100(61)$ & $\begin{array}{l}\text { Cross } \\
\text { sectional }\end{array}$ & $48 / 52$ & $79 / 100(79)$ & $\begin{array}{l}\text { NTproBNP Elecsys } \\
\text { (Roche, USA) }\end{array}$ & $\begin{array}{l}\text { Cardiology discharge } \\
\text { diagnosis }\end{array}$ & $\begin{array}{l}\text { Patient selection: low; index test: } \\
\text { high; reference standard: high; } \\
\text { flow and timing: low; overall: high }\end{array}$ \\
\hline $\begin{array}{l}\text { Eckstein } 2012,{ }^{46} \\
\text { emergency department. } \\
\text { Overlap with Maisel } \\
2010^{40} \text { data. Data only } \\
\text { extracted for NTproBNP } \\
\text { to avoid double counting } \\
\text { for MRproANP }\end{array}$ & $632(\mathrm{NR})$ & $\begin{array}{l}\text { Prospective } \\
\text { cohort }\end{array}$ & NR & $\begin{array}{c}362 / 632 \\
(57)\end{array}$ & $\begin{array}{l}\text { NTproBNP Elecsys } \\
\text { (Roche, USA) }\end{array}$ & $\begin{array}{l}\text { Retrospective review by } \\
\text { two cardiologists }\end{array}$ & $\begin{array}{l}\text { Patient selection: low; index test: } \\
\text { low; reference standard: low; flow } \\
\text { and timing: low; overall: low }\end{array}$ \\
\hline
\end{tabular}

$\mathrm{BNP}=\mathrm{B}$ type natriuretic peptide; $\mathrm{NTproBNP}=\mathrm{N}$ terminal probrain natriuretic peptide; $\mathrm{MRproANP}=$ mid-regional proatrial natriuretic peptide; $\mathrm{NR}=$ not recorded. 
Table 2/ Sensitivity, specificity, positive predictive and negative predictive values for all peptides. Values in brackets are pooled $95 \%$ confidence intervals or range*

\begin{tabular}{|c|c|c|c|c|c|c|c|c|}
\hline $\begin{array}{l}\text { Natriuretic peptide } \\
\text { (threshold) }\end{array}$ & $\begin{array}{l}\text { No of } \\
\text { studies }\end{array}$ & No & $\begin{array}{l}\text { No of } \\
\text { cases }\end{array}$ & Sensitivity \% & Specificity \% & $\begin{array}{l}\text { Positive predictive } \\
\text { value }\end{array}$ & $\begin{array}{c}\text { Negative predictive } \\
\text { value }\end{array}$ & $I^{2}(\%)$ \\
\hline \multicolumn{9}{|l|}{$\begin{array}{l}\text { B type natriuretic } \\
\text { peptide: }\end{array}$} \\
\hline$\leq 100 \mathrm{ng} / \mathrm{L}$ & 19 & 6950 & 3049 & 0.95 (0.93 to 0.96$)$ & 0.63 (0.52 to 0.73$)$ & $0.67(0.63$ to 0.75$)$ & 0.94 (0.90 to 0.96$)$ & 98 \\
\hline $100-500 \mathrm{ng} / \mathrm{L}$ & 20 & 4543 & 2160 & 0.85 (0.81 to 0.88$)$ & 0.86 (0.79 to 0.91$)$ & $0.85(0.78$ to 0.90$)$ & $0.86(0.82$ to 0.89$)$ & 97 \\
\hline$\geq 500 \mathrm{ng} / \mathrm{L}$ & 4 & 283 & 145 & $\begin{array}{c}0.35(0.17-0.56) \text { to } \\
0.83(0.69-0.92)^{*}\end{array}$ & $\begin{array}{c}0.78(0.56-0.93) \text { to } \\
1.00(0.91-1.00)^{*}\end{array}$ & $\begin{array}{c}0.89(0.75-0.96) \text { to } 1.0 \\
(0.63-1.0)^{*}\end{array}$ & $\begin{array}{c}0.55(0.69-0.80) \text { to } \\
0.69(0.48-0.84)^{*}\end{array}$ & - \\
\hline \multicolumn{9}{|l|}{$\begin{array}{l}\mathrm{N} \text { terminal probrain } \\
\text { natriuretic peptide: }\end{array}$} \\
\hline$\leq 300 \mathrm{ng} / \mathrm{L}$ & 10 & 3349 & 1695 & 0.99 (0.97 to 1.00$)$ & $0.43(0.26$ to 0.62$)$ & 0.64 (0.57 to 0.73$)$ & 0.98 (0.89 to 1.0$)$ & 94 \\
\hline $300-1800 \mathrm{ng} / \mathrm{L}$ & 13 & 3223 & 1652 & $0.90(0.86$ to 0.93$)$ & 0.76 (0.69 to 0.82$)$ & $0.80(0.74$ to 0.84$)$ & $0.88(0.82$ to 0.92$)$ & 97 \\
\hline$\geq 1800 \mathrm{ng} / \mathrm{L}$ & 3 & 840 & 444 & $\begin{array}{c}0.67(0.60-0.73) \text { to } \\
0.87(0.81-0.92)^{*}\end{array}$ & $\begin{array}{c}0.72(0.63-0.80) \text { to } \\
0.95(0.91-0.98)^{*}\end{array}$ & $\begin{array}{c}0.80(0.73-0.86) \text { to } \\
0.94(0.89-0.97)^{\star}\end{array}$ & $\begin{array}{c}0.71(0.65-0.76) \text { to } \\
0.82(0.73-0.89)^{\star}\end{array}$ & - \\
\hline \multicolumn{9}{|l|}{$\begin{array}{l}\text { Mid-regional proatrial } \\
\text { natriuretic peptide: }\end{array}$} \\
\hline$\leq 120 \mathrm{pmol} / \mathrm{L}$ & 2 & 1892 & 705 & $\begin{array}{c}0.95(0.90-0.98) \text { to } \\
0.97(0.95-0.98)^{*}\end{array}$ & $\begin{array}{c}0.56(0.47-0.65) \text { to } \\
0.60(0.57-0.63)^{*}\end{array}$ & $\begin{array}{l}0.56(0.53-0.59) \text { to } \\
0.72(0.65-0.79)^{*}\end{array}$ & $\begin{array}{l}0.90(0.80-0.96) \text { to } \\
0.97(0.96-0.98)^{*}\end{array}$ & - \\
\hline$>120 \mathrm{pmol} / \mathrm{L}$ & 3 & 916 & 406 & $\begin{array}{c}0.84(0.77-0.89) \text { to } \\
0.98(0.94-1.00)^{*}\end{array}$ & $\begin{array}{c}0.40(0.34-0.46) \text { to } \\
0.84(0.77-0.90)^{*}\end{array}$ & $\begin{array}{c}0.41(0.35-0.47) \text { to } \\
0.86(0.79-0.91)^{\star}\end{array}$ & $\begin{array}{c}0.82(0.74-0.88) \text { to } \\
0.98(0.93-1.00)^{\star}\end{array}$ & - \\
\hline
\end{tabular}

*A sensitivity or specificity range is given where there were insufficient number of studies to conduct diagnostic meta-analysis and generate a pooled sensitivity and specificity value. Table 1 shows the setting of each study and assay used. 
Table 3 | Investigation of heterogeneity

\begin{tabular}{|c|c|c|c|c|}
\hline Variables & Setting & Assay & Prevalence & Overall study quality \\
\hline \multicolumn{5}{|c|}{ B type natriuretic peptide } \\
\hline \multicolumn{5}{|l|}{$\leq 100 \mathrm{ng} / \mathrm{L}:$} \\
\hline Sensitivity $(95 \% \mathrm{Cl})$ & 0.95 (0.91 to 0.97$)$ & $0.94(0.91$ to 0.96$)$ & $0.96(0.92$ to 0.98$)$ & $0.92(0.84$ to 0.96$)$ \\
\hline$P$ value & 0.89 & 0.6 & 0.5 & 0.13 \\
\hline Specificity $(95 \% \mathrm{Cl})$ & 0.56 (0.38 to 0.72$)$ & 0.66 (0.49 to 0.79$)$ & 0.62 (0.36 to 0.83$)$ & 0.69 (0.43 to 0.87$)$ \\
\hline$P$ value & 0.51 & 0.76 & 0.96 & 0.64 \\
\hline \multicolumn{5}{|l|}{$100-500 \mathrm{ng} / \mathrm{L}:$} \\
\hline Sensitivity $(95 \% \mathrm{Cl})$ & $0.87(0.82$ to 0.91$)$ & 0.83 (0.77 to 0.88$)$ & $0.82(0.71$ to 0.90$)$ & 0.80 (0.68 to 0.88$)$ \\
\hline$P$ value & 0.37 & 0.68 & 0.62 & 0.29 \\
\hline Specificity $(95 \% \mathrm{Cl})$ & 0.81 (0.69 to 0.89$)$ & $0.90(0.81$ to 0.95$)$ & $0.89(0.73$ to 0.96$)$ & $0.92(0.78$ to 0.97$)$ \\
\hline$P$ value & 0.38 & 0.45 & 0.65 & 0.36 \\
\hline \multicolumn{5}{|c|}{$\mathrm{N}$ terminal probrain natriuretic peptide } \\
\hline \multicolumn{5}{|l|}{$\leq 300$ ng/L: } \\
\hline Sensitivity $(95 \% \mathrm{Cl})$ & 0.99 (0.97 to 0.99$)$ & 0.96 (0.77 to 0.99$)$ & $0.98(0.93$ to 1.00$)$ & $0.98(0.90$ to 1.00$)$ \\
\hline$P$ value & 0.97 & 0.21 & 0.81 & 0.56 \\
\hline Specificity $(95 \% \mathrm{Cl})$ & $0.77(0.57$ to 0.89$)$ & $0.42(0.06$ to 0.89$)$ & $0.93(0.84$ to 0.97$)$ & $0.56(0.15$ to 0.90$)$ \\
\hline$P$ value & 0.53 & 0.37 & $<0.01^{*}$ & 058 \\
\hline \multicolumn{5}{|c|}{$\mathrm{N}$ terminal probrain natriuretic peptide } \\
\hline \multicolumn{5}{|l|}{ 300-1800 ng/L: } \\
\hline Sensitivity $(95 \% \mathrm{Cl})$ & $0.90(0.85$ to 0.94$)$ & 0.92 (0.72 to 0.98$)$ & $0.93(0.84$ to 0.97$)$ & $0.91(0.81$ to 0.96$)$ \\
\hline$P$ value & 0.91 & 0.75 & 0.46 & 0.82 \\
\hline Specificity $(95 \% \mathrm{Cl})$ & $0.78(0.70$ to 0.85$)$ & $0.58(0.30$ to 0.82$)$ & $0.84(0.71$ to 0.92$)$ & $0.78(0.62$ to 0.88$)$ \\
\hline$P$ value & 0.67 & 0.17 & 0.22 & 0.83 \\
\hline
\end{tabular}




\section{Figures}

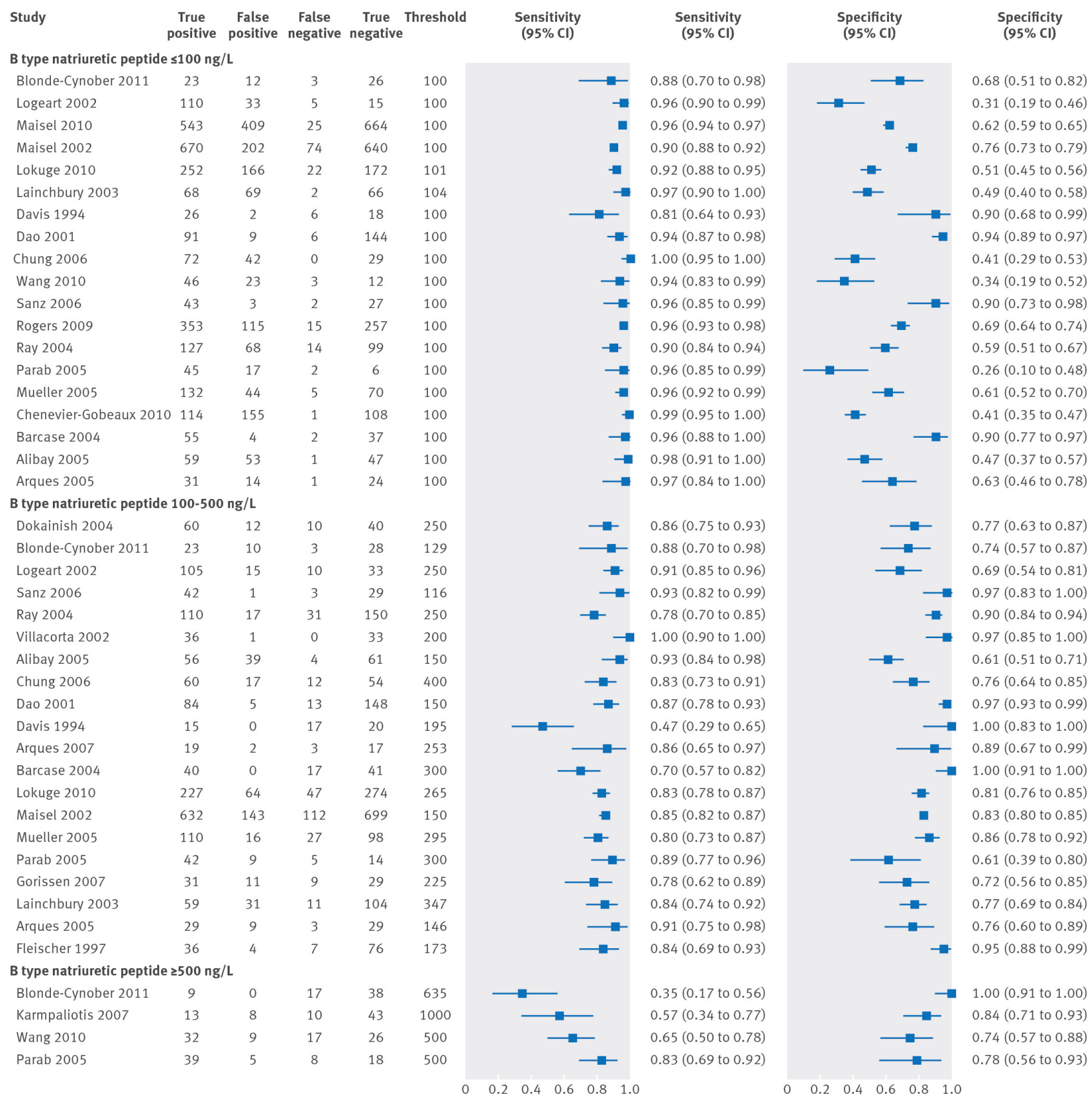

Fig 1 Paired sensitivity and specificity plots for B type natriuretic peptide at three threshold levels 


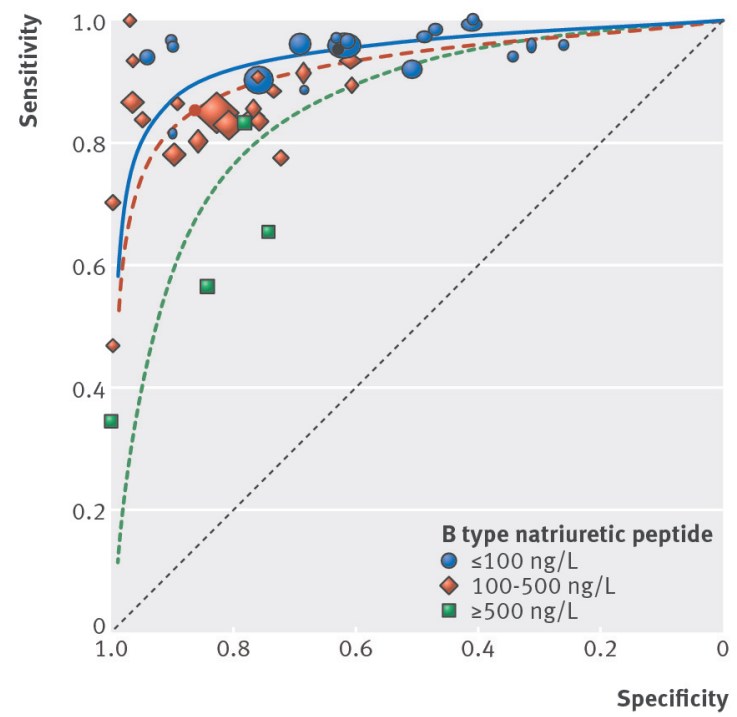

Fig 2 Results for B type natriuretic peptide (separated by threshold) displayed in summary receiver operating characteristic space. Size of symbol indicates study size and solid circles show pooled sensitivity or specificity value (for $>500 \mathrm{ng} / \mathrm{L}$ insufficient data were available to pool results)

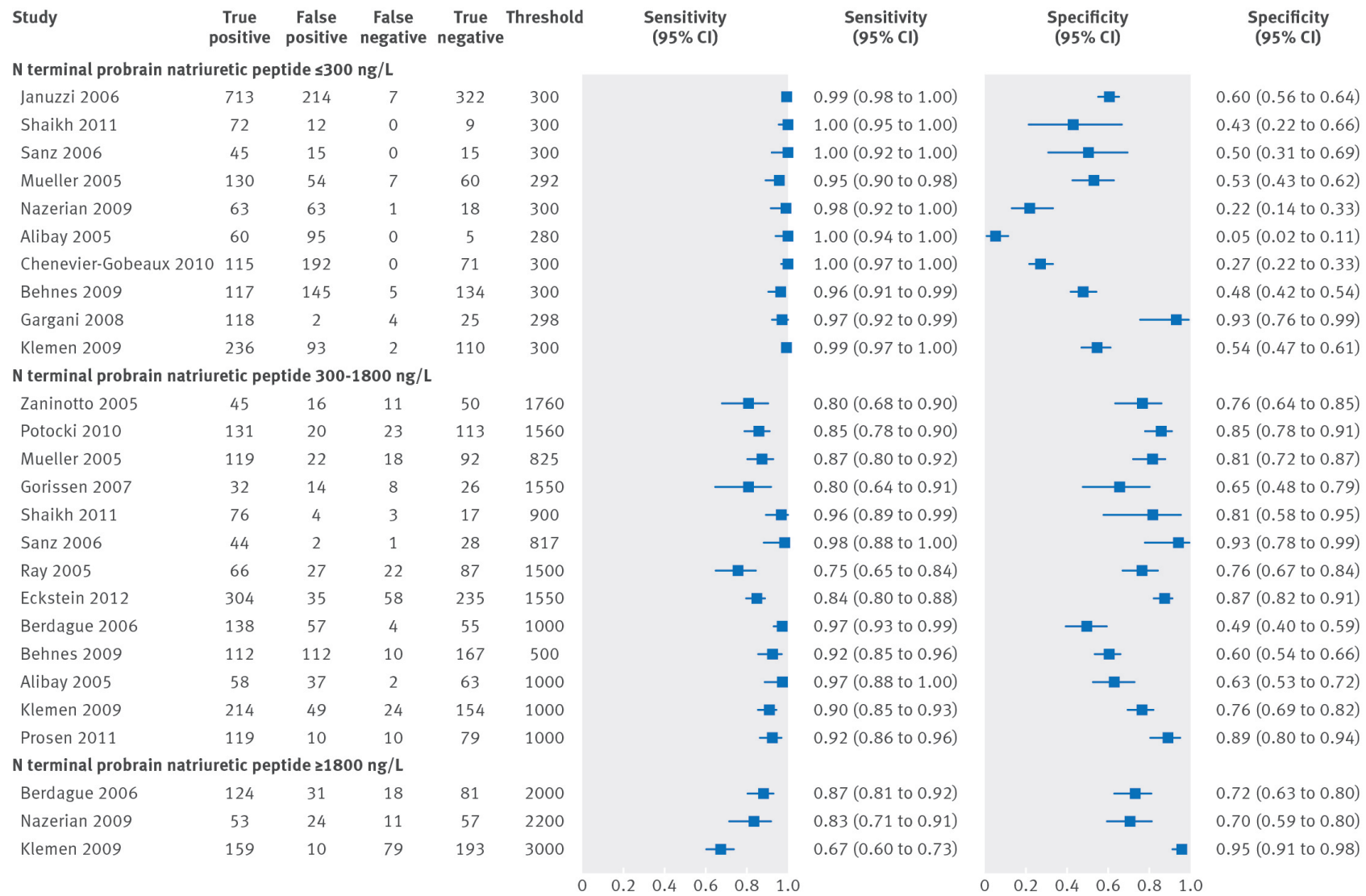

Fig 3 Paired sensitivity and specificity plots for $\mathrm{N}$ terminal probrain natriuretic peptide at three threshold levels 


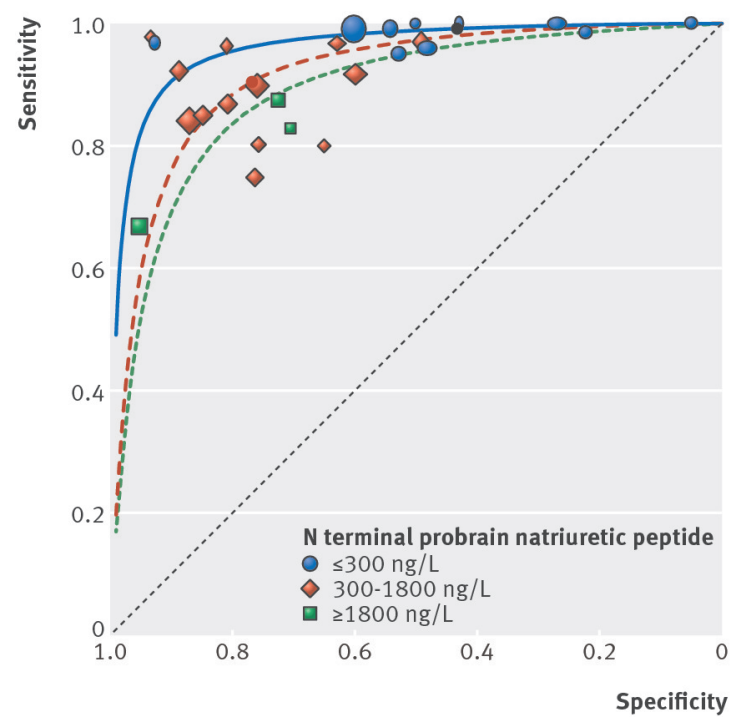

Fig 4 Results for $\mathrm{N}$ terminal probrain natriuretic peptide (separated by threshold) displayed in summary receiver operating characteristic space. Size of symbol indicates study size and solid circles show pooled sensitivity or specificity value according to threshold (for $>500 \mathrm{ng} / \mathrm{L}$ insufficient data was available to pool results)

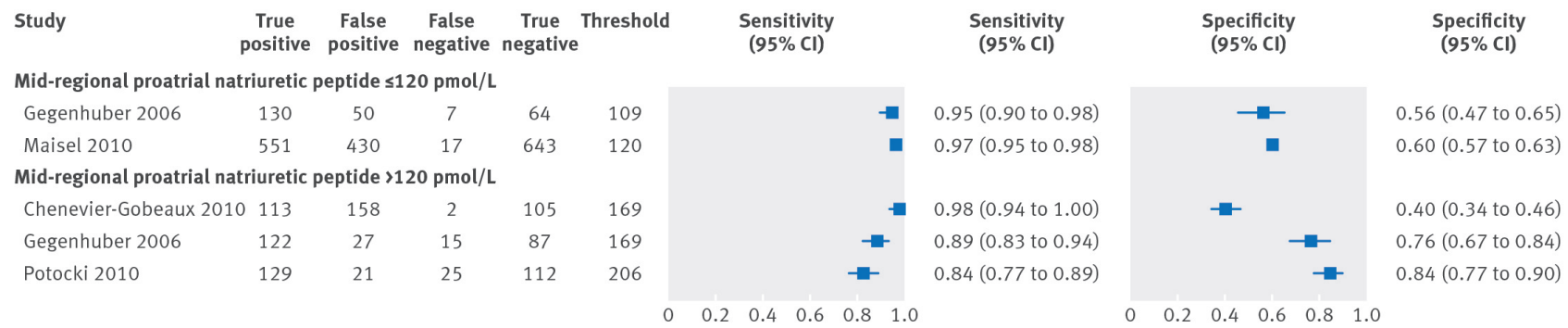

Fig 5 Paired sensitivity and specificity plots for mid-regional proatrial natriuretic peptide at two threshold levels

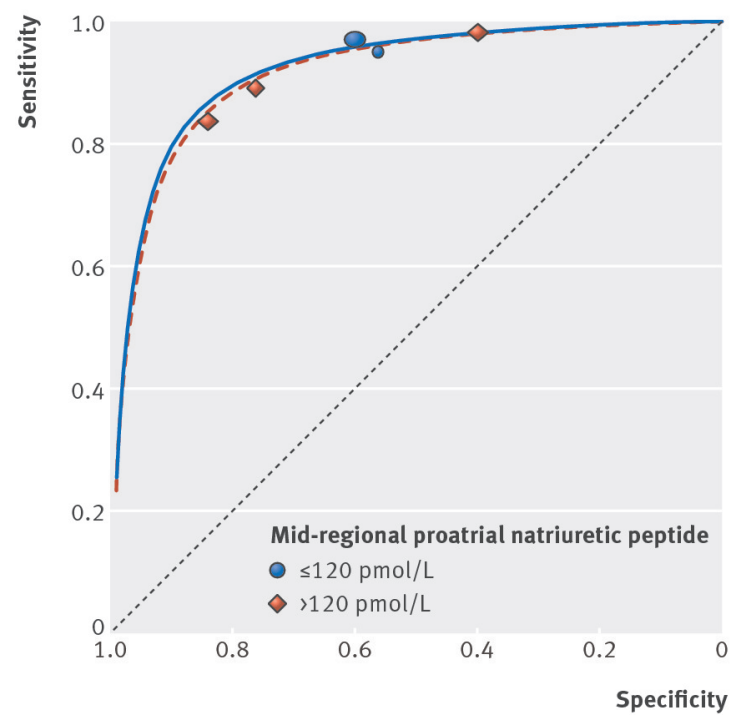

Fig 6 Results for mid-regional proatrial natriuretic peptide (separated by threshold) displayed in summary receiver operating characteristic space. Size of symbol indicates study size 


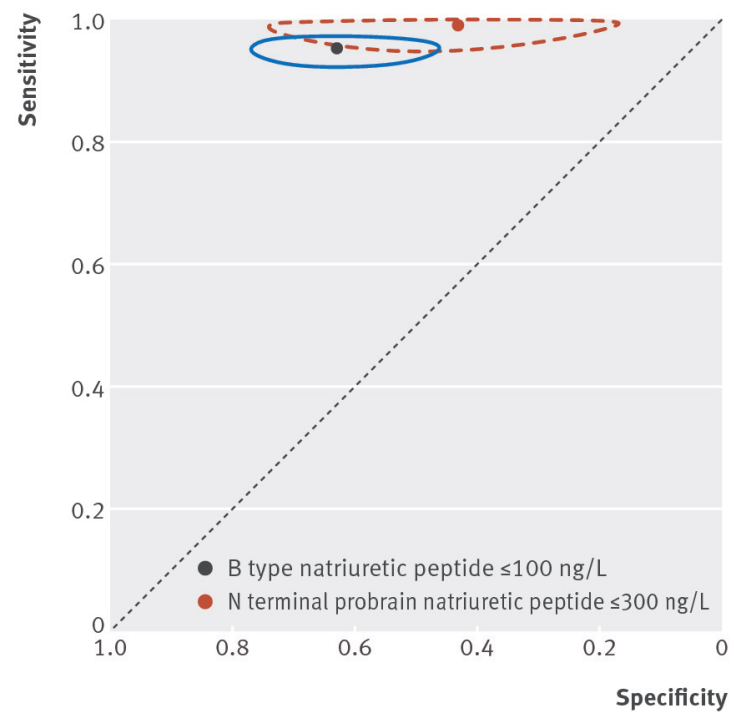

Fig 7 Comparison of pooled B type natriuretic peptide and $\mathrm{N}$ terminal probrain natriuretic peptide diagnostic accuracy results at lowest threshold (95\% confidence region indicated as circles surrounding solid points) 